AperTO - Archivio Istituzionale Open Access dell'Università di Torino

\title{
TG/DSC study of the thermal behaviour of hazardous mineral fibres
}

\section{This is a pre print version of the following article:}

Original Citation:

Availability:

This version is available http://hdl.handle.net/2318/1567980

since 2017-05-18T15:36:03Z

Published version:

DOI:10.1007/s10973-015-4939-8

Terms of use:

Open Access

Anyone can freely access the full text of works made available as "Open Access". Works made available under a Creative Commons license can be used according to the terms and conditions of said license. Use of all other works requires consent of the right holder (author or publisher) if not exempted from copyright protection by the applicable law. 
This is the preprint of the contribution published as:

Bloise, Andrea, Manuela Catalano, Eugenio Barrese, Alessandro Francesco Gualtieri, Nicola Bursi Gandolfi, Silvana Capella, and Elena Belluso. 2015. 'TG/DSC Study of the Thermal Behaviour of Hazardous Mineral Fibres'. Journal of Thermal Analysis and Calorimetry 123 (3): 2225-39. doi:10.1007/s10973-015-4939-8.

The publisher's version is available at:

http://link.springer.com/article/10.1007/s10973-015-4939-8

When citing, please refer to the published version.

\section{Link to this full text:}

http://hdl.handle.net/2318/1567980 


\title{
TG/DSC study of the thermal behaviour of hazardous mineral fibres
}

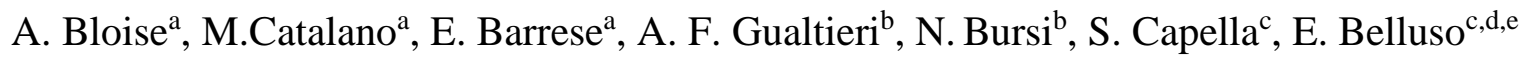

a) Dipartimento di Biologia, Ecologia e Scienze della Terra, Università della Calabria, Via Pietro Bucci, Cubo 15b, 87036 Rende, Italy

b) Dipartimento di Scienze Chimiche e Geologiche, Università di Modena e Reggio Emilia, Via S. Eufemia 19, I-41121 Modena, Italy

c) Dipartimento di Scienze della Terra, Università di Torino, Via Valperga Caluso 35, 10125 Torino, Italy

d) CNR, Istituto di Geoscienze e Georisorse, Unità di Torino, Via Valperga Caluso 35, 10125 Torino, Italy

e) Nanostructured Interfaces and Surfaces, Centro Interdipartimentale di Eccellenza, Università di Torino, Italy

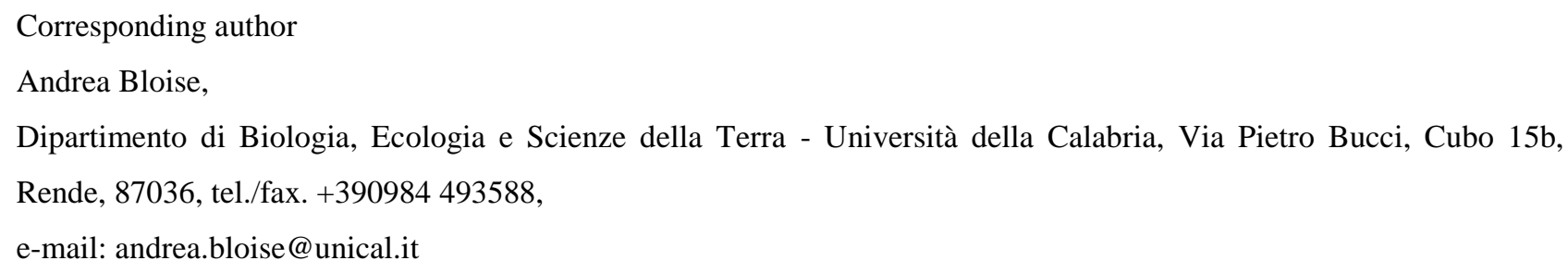




\begin{abstract}
For the first time, this paper reports a systematic and comparative study of the thermal behaviour of fibres of social, health, economic and industrial relevance using thermogravimetric and differential scanning calorimetry (TG/DSC). The mineral fibres selected for the study are: three chrysotiles samples, crocidolite, tremolite asbestos, amosite, anthophyllite asbestos and fibrous erionite. Powder X-ray diffraction (PXRD) and scanning electron microscopy combined with energy dispersive spectrometry (SEM/EDS) were used for the characterization of the mineral fibres before and after heating at 1000 or $1100{ }^{\circ} \mathrm{C}$ to identify the products of the thermal decomposition at a microscopic and structural scale and characterize their thermal behaviour.

TG/DSC data allowed the determination of the structural water content and temperature stability. Furthermore thermal analysis provided a sensitive and reliable technique for the detection of small quantities of different mineral phases occurring as impurities. After thermal treatment, fibrous samples were completely transformed into various iron oxide, cristobalite and other silicate phases which preserved the original overall fibrous morphology (as pseudomorphosis). Only crocidolite at $1100{ }^{\circ} \mathrm{C}$ was partially melted and an amorphous surface was observed.
\end{abstract}

Keywords: Mineral fibres, Asbestos, Thermal behaviour, Dehydroxylation, Pseudomorphosis.

\title{
Introduction
}

Among the minerals which are considered particularly hazardous for human health, the most notorious display a fibrous-asbestiform crystal habit [1]. It is now widely accepted to include in the family of the so-called asbestos mineral the following species: serpentine chrysotile, five amphibole species named tremolite and actinolite asbestos, crocidolite, amosite, anthophyllite asbestos and the fibrous zeolite erionite [2]. 
Chrysotile is a member of the serpentine group, a 1:1 layer silicate (constituted by a tetrahedral and a trioctahedral sheet) whose layers are rolled so to assume a characteristic fibrous habit $[3,4]$. Amphiboles are double-chain silicates which may display a fibrous habit being structurally elongated in one preferred crystal direction. Finally, erionite is a common fibrous/acicular zeolite with an hexagonal, cage-like structure composed of a framework of linked tetrahedral $[5,6]$. Despite their outstanding technological properties (e. g. low thermal conductivity, high mechanical strength, workability, among the others) which prompt their widespread industrial applications, asbestos minerals are considered hazardous. In general, all asbestos fibres if inhaled are thought to induce malignant mesothelioma, lung cancer (in combination with other factors), and other lung diseases $[7,8]$. According to the existing regulations, amphibole asbestos fibres are banned worldwide whereas chrysotile is banned in only $28 \%$ of the countries worldwide. In the other countries, safe use of chrysotile is admitted. Asbestos erionite unfortunately is not regulated but listed by International Agency for Research of Cancer (IARC) as substance carcinogenic to humans. As a matter of fact, in vivo studies unequivocally proved that asbestiform erionite is more tumorigenic than chrysotile and crocidolite asbestos [9].

Since the advent of industrial age, asbestos fibres have been extensively used in an endless number of industrial applications and especially to manufacture various types of artefacts (asbestos cement, disc brake pads, pipes, reinforcing agents, fire retardants etc). In those countries where all asbestos minerals are banned, and remediation policies are fostered, many attempts were made to detoxify asbestos minerals by using different techniques [10-12]. In this regard, many projects and patents have dealt with the possible disposal and re-use of asbestos-containing materials (ACM) via the crystal-chemical transformation induced by thermal treatment [13-18]. However, it must be considered that the thermal transformations sequence of asbestos-containing materials (ACM), composed of a variety of different crystalline and amorphous phases, is totally different with respect to the transformations sequence of pure asbestos minerals. 
Concerning pure chrysotile, it has been demonstrated that its structure collapse at around $650{ }^{\circ} \mathrm{C}$ with early recrystallization at about $800{ }^{\circ} \mathrm{C}$ into anhydrous silicates such as forsterite and amorphous silica [19]. With respect to chrysotile, papers dealing with the thermal decomposition of pure amphibole asbestos and erionite are rare. As a matter of fact, only few studies were devoted to the thermal decomposition of pure amphibole asbestos up to $1100{ }^{\circ} \mathrm{C}$ and rare data report on the new phases appeared after thermal treatment. Thermal decomposition of fibrous amphibole minerals have been generally limited to asbestos minerals of commercial value or health concern such as crocidolite [20-25] and amosite [23, 26, 27]. Moreover, in some papers regarding the thermal analysis of amphiboles asbestos, a full picture of their thermal behaviour is not given [28]. Regarding erionite, the thermal behaviour of a sample from Jersey Nevada (USA) is described in only one paper [29] which showed that the main endothermic event has occurred at about $140{ }^{\circ} \mathrm{C}$ but did not report the TG curve neither the temperature of the structural collapse. In this scenario, the aim of this study was to systematically investigate and compare the thermal behaviour (TG/DSC) as well as the phase transformations of the most relevant mineral fibres during heating up to 1000 or $1100{ }^{\circ} \mathrm{C}$. The study was performed on eight selected fibrous minerals including chrysotile, crocidolite (asbestiform riebeckite), tremolite asbestos, anthophyllite asbestos, amosite (grunerite asbestos) and fibrous erionite object of many important biomedical studies [30, 31]. Four fibrous species (chrysotile, crocidolite, amosite, and anthophyllite asbestos) were distributed by the International Union Against Cancer (UICC).

The deep knowledge of thermal behaviour of these asbestos minerals may deliver data relevant for the understanding of the crystal-chemical transformations of asbestos through thermal treatment and for the identification of asbestos mineral fibres in bulk natural samples using TG/DSC. Furthermore, since both asbestos samples and asbestiform erionite are used for in vitro studies to test their cyto-toxicity [30,31], the determination of the presence of impurities may be crucial as such contaminants may adversely affect the experimental results. 


\section{Materials and methods}

Table 1 reports the nature and chemical formula (after Pollastri et al., 2015 [32]) of the eight investigated fibres: UICC chrysotile from Canada; chrysotile from Balangero (Italy); chrysotile from Val Malenco (Italy); UICC crocidolite from Koegas Mine, Northern Cape (S. Africa); tremolite asbestos from Val d'Ala (Italy); UICC amosite from Penge mine, Northern Province (S. Africa); UICC anthophyllite asbestos from Paakkila (Finland) and asbestiform erionite from Jersey Nevada (USA). The major focus of the work was to systematically characterize the mineral fibres by thermal analysis specifically thermogravimetric (TG), derivative thermogravimetric (DTG), differential scanning calorimetry (DSC), derivative differential scanning calorimetry (DDSC). TG and DSC were performed in an alumina crucible under a constant nitrogen flow of $30 \mathrm{~cm}^{3} \mathrm{~min}^{-1}$ with a Netzsch STA 449 C Jupiter in a $25-1000$ and $25-1100{ }^{\circ} \mathrm{C}$ temperature range, with a heating rate of $10^{\circ} \mathrm{C} / \mathrm{min}$. Instrumental precision was checked by six repeated collections on a kaolinite reference sample revealing good reproducibility (instrumental theoretical $\mathrm{T}$ precision of \pm $1.2^{\circ} \mathrm{C}$ ) and theoretical weight sensitivity of $0.10 \mu \mathrm{g}$, DSC detection limit $<1 \mu \mathrm{W}$. Samples were powdered by dry-grinding in an agate mortar; about $40 \mathrm{mg}$ of each sample were used in all collections. Owing to the remarkable length of the chrysotile fibres from Val Malenco, before grinding they were cut with scissors.

A qualitative phase analysis, both of natural and heated samples, was performed according to the powder X-ray diffraction method (PXRD) using a Bruker D8 Advance X-ray diffractometer at 40 $\mathrm{kV}$ and $40 \mathrm{~mA}$. The instrument is equipped with a copper tube and curved graphite monochromator. Scans were recorded in the range of $3-66^{\circ} 2 \theta$, with a step interval of $0.02^{\circ} 2 \theta$ and a step-counting time of $3 \mathrm{~s} / \mathrm{step}$. EVA software (DIFFRACplus EVA) was used to identify the mineral phases and experimental peaks being compared with the 2005 PDF2 reference patterns. The morphology of the samples before and after thermal analysis was investigated by scanning electron microscopy (SEM) 
using an Environmental Scanning Electron Microscope FEI QUANTA 200 equipped with an

\section{Results and discussion}

\section{Chrysotile}

The thermal analysis for chrysotile UICC (Fig. 1) showed four endothermic peaks at 226, 401, 520 and $633{ }^{\circ} \mathrm{C}$. The first peak at $226{ }^{\circ} \mathrm{C}$ may be due to the dehydroxylation of pyroaurite [33]; the peak at $401{ }^{\circ} \mathrm{C}$ to the dehydroxylation of brucite and de-oxygenation of pyroaurite $[33,34]$; the very weak peak at $520{ }^{\circ} \mathrm{C}$ is thought to be generated by the decarbonation of siderite [35], likely present as very minor impurity; the wide peak at $633{ }^{\circ} \mathrm{C}$ to the chrysotile dehydroxylation $[22,36]$. The weak endothermic event at $901{ }^{\circ} \mathrm{C}$ on DTG (Fig. 1) curve was ascribed to talc dehydroxilation [37, 38]. It is possible that the wide endothermic event at $633{ }^{\circ} \mathrm{C}$ hides minor endothermic events due to the decarbonation of calcite, dolomite, and/or dehydroxylation of clinochlore [34, 36, 37]. The TG curve showed a weight loss of $0.91 \%$ below $110{ }^{\circ} \mathrm{C}$ due to adsorbed water while the main weight loss of $12.22 \%$ was due to chrysotile dehydroxylation (Table 2).

Our findings are in line with previous literature data on chrysotile dehydration mechanisms and high- $T$ crystallization [39-42]. The product of the dehydroxylation of chrysotile recrystallized to forsterite $[19,43,44]$ caused a sharp exothermic peak at $823^{\circ} \mathrm{C}$ (Fig. 1, Table 3). Indeed, the corresponding PXRD pattern (Fig. 2) of the chrysotile UICC after thermal treatment confirmed the presence of the forsterite.

The DSC curve of the chrysotile from Balangero exhibited one major effect (Fig. 3) at $660{ }^{\circ} \mathrm{C}$ related to the chrysotile dehydroxylation with a weight loss of $11.80 \%$. As already described above, the weak endothermic effect (Fig. 3, Table 3) at $402{ }^{\circ} \mathrm{C}$ is due to brucite [34] breakdown. In the DTG curve the peak at $869^{\circ} \mathrm{C}$ was related to the decarbonation of dolomite [45]. The DSC weak 
shoulder effect at $938^{\circ} \mathrm{C}$ which was clearly recorded on DDSC curve was related to the talc dehydroxilation [38]. Again, the wide endothermic event at $660{ }^{\circ} \mathrm{C}$ may hide minor endothermic events due to the I decarbonation of dolomite, calcite, and clinochlore [34, 36, 37]. The weak endothermic effect at $717^{\circ} \mathrm{C}$ visible on the DTG curve (Fig. 3) is due to the antigorite dehydroxylation $[36,46]$. The effect on TG curve $(-0.57 \mathrm{wt} \%)$ below $110{ }^{\circ} \mathrm{C}$ was ascribed to the release of humidity adsorbed at the sample surface while the total weight loss at $1000{ }^{\circ} \mathrm{C}$ was of $14.9 \%$ (Table 2). On the DSC curve the exothermic peak at $822{ }^{\circ} \mathrm{C}$ (Fig. 3) was related to the crystallization of forsterite as determined by PXRD after thermal treatment at $1000{ }^{\circ} \mathrm{C}$ (Fig. 2). The TG curve for the chrysotile from Val Malenco (Fig. 4) showed a continuous weight loss mainly due to the decomposition of chrysotile in correspondence with the major endothermic event at 652 ${ }^{\circ} \mathrm{C}$ (see the DSC curve in Fig. 4). Dehydroxylation of chrysotile causes a weight loss of $12.01 \%$. DTG weak effect at $760{ }^{\circ} \mathrm{C}$ (Fig. 4) is the diagnostic signal [47] of the presence of antigorite in the sample which was also detected by TEM analysis on the same sample by Cattaneo et al. [48]. Broad DTG and DSC signals in the $25-110{ }^{\circ} \mathrm{C}$ range were due to adsorbed water (weight loss of $0.54 \%$ ) while the total weight loss at $1000{ }^{\circ} \mathrm{C}$ was $13.35 \%$ (Table 2). A sharp exothermic peak at $820{ }^{\circ} \mathrm{C}$ indicates the crystallization of forsterite $[19,43,44]$ as confirmed by PXRD data (Fig. 2). As showed in Fig. 5 the curves of the three chrysotile samples have similar trend; no significant variation in the exothermal peaks (range $820-823^{\circ} \mathrm{C}$ ) was observed, while a slight difference in the main endothermic effect occurred. The endothermic peak observed for the chrysotile UICC shows a shift versus lower temperature $\left(633^{\circ} \mathrm{C}\right)$ with respect to both chrysotile from Val Malenco $\left(652{ }^{\circ} \mathrm{C}\right)$ and chrysotile from Balangero $\left(660^{\circ} \mathrm{C}\right)$. The different temperature of chrysotile decomposition (range $633-660^{\circ} \mathrm{C}$ ) of the three chrysotile samples may be due to the different fibre size (width and length) distribution and the presence of different amount of $\mathrm{Fe}[43,49]$ and $\mathrm{Ni}$ [44] substitute for Mg in octahedral sheet [32]. The relationships between distribution size, Ni, Fe content and change of temperature stability of chrysotile are complex. In fact, as recently demonstrated, the thermal 
shift in chrysotile decomposition can be also related to the presence of trace elements in its structure

(i.e. $\mathrm{Li}, \mathrm{As}, \mathrm{Sb}$ ) [50] which may control the range of temperature over that the structure collapses. The TG curves of the three specimens of chrysotile showed a weight loss of about $12 \%$ (Table 2) due to their decomposition $[19,51]$. These data match the theoretical and experimental values of mass loss observed in natural and synthetic chrysotile fibres reported in literature $[19,43,47,51]$. A representative set of secondary electron SEM images showing the morphology of chrysotile before and after thermal analysis at $1000{ }^{\circ} \mathrm{C}$ is reported in Fig. 6 . The unheated fibres of chrysotile samples appear arranged in bundles (Fig. 6a, 6d) and curved with their typical wavy appearance (Fig. 6g). The splitting in fibrils starting from the fibre bundle is shown in Figures 6a and 6d . After thermal treatment at $1000{ }^{\circ} \mathrm{C}$, chrysotile fibres recrystallize in forsterite apparently retaining the original fibrous crystal habit (pseudomorphosis phenomenon) $[52,53]$ and appearing curved and still flexible (Fig. 6b, 6e, 6h). However, at higher magnification (HM) the apparent fibres turn out to be a continuous sequence of sub-cylindrical particles with basis both sharp and perpendicular to the original fibre axis [16], approximately $100 \mathrm{~nm}$ in length (Fig. 6c), Sometimes, the new silicate is constituted by sub-spherical particles disposed not very tidily along the axis (Fig. $6 f$ ). The original cleavage parallel to the fibre axis is lost (Fig. 6c). Therefore, the eventual fracture of the transformed pseudo-morphic fibres occurs at the particle boundaries and not along the fibre axis. Moreover, as observed in Fig 6i, the typical smooth surface of chrysotile fibres is completely lost becoming very rough.

\section{Amphiboles}

\section{Crocidolite}

The DTG curve of crocidolite (Fig. 7) shows a major endothermic event at $648{ }^{\circ} \mathrm{C}$ related to iron oxidation accompanied by dehydrogenation and/or dehydroxylation. The structure does not show collapse which occurs at higher temperature [24] with a corresponding weight loss of $2.18 \%$ in the 
range $110-680{ }^{\circ} \mathrm{C}$ of the TG curve. No weight loss of crocidolite was observed above $700{ }^{\circ} \mathrm{C}$ in agreement with Fujishige et al. [54]. As it can be observed in the DTG curve (Fig. 7), the partial oxidation of ferrous iron content in the crocidolite takes place in the range $200-580{ }^{\circ} \mathrm{C}$ [55], as confirmed by the three weight gain peaks at 205,360 , and $570{ }^{\circ} \mathrm{C}$ (Fig. 7). Although the detailed discussion of the processes is not the object of this paper, it is necessary to point out that the oxidation of crocidolite is essentially a dehydrogenation, as long as dehydroxylation occurs [21] so that the mechanism of oxidation was considered to be dependent on migration of protons and electrons through the crystal. Indeed, when hydrated silicates containing ferrous iron are heated the constitutional hydroxyl decomposes and iron may change its valence state. Oxidation may result from either the incorporation of oxygen into the material (oxygenation) or a dehydrogenation with the following mechanism: $\mathrm{Fe}^{2+}+\mathrm{OH}^{-} \rightarrow \mathrm{Fe}^{3+}+\mathrm{O}^{2-}+\mathrm{H}[56]$.

The DSC curve up to $700{ }^{\circ} \mathrm{C}$ showed two exothermic and two endothermic effect: $320{ }^{\circ} \mathrm{C}, 431{ }^{\circ} \mathrm{C}$, $354{ }^{\circ} \mathrm{C}$ and $649{ }^{\circ} \mathrm{C}$ respectively (Table 3). The first exothermic effect at $320^{\circ} \mathrm{C}$ was related to the crocidolite dehydrogenation as confirmed by the weight gain peak at $360{ }^{\circ} \mathrm{C}$ in the DTG curve due to consequent $\mathrm{Fe}^{2+}$ oxidation. The endothermic effect at $354{ }^{\circ} \mathrm{C}$ should be related to the dehydroxylation of hydroxyl water of the crocidolite with a consequent formation of oxy-crocidolite (crocidolite partially dehydrogenated) [23]. The exothermic peak at $431{ }^{\circ} \mathrm{C}$ (Fig. 7) was related to the second dehydrogenation as confirmed by the DTG weight gain at $570{ }^{\circ} \mathrm{C}$ which is a consequence of $\mathrm{Fe}^{2+}$ oxidation. The weak endothermic effect at $649{ }^{\circ} \mathrm{C}$ represents the total dehydroxylation of crocidolite in good agreement whit data reported by Hodgson et al. [20] in which the total dehydroxylation of crocidolite was observed in the range of $570-700{ }^{\circ} \mathrm{C}$. The broad exothermic effect at $850{ }^{\circ} \mathrm{C}$ (Fig. 7) was related to the structure collapse and formation of magnetite, cristobalite, and a pyroxene phase (acmite, $\left.\mathrm{NaFeSi}_{2} \mathrm{O}_{6}\right)$ [20]. At $928^{\circ} \mathrm{C}$, the DSC curve shows an endothermic peak due to the conversion of magnetite to hematite. Indeed, in the DTG curve the peak at $928^{\circ} \mathrm{C}$ stems from the oxidation of the ferrous iron 
present in magnetite $\left(\mathrm{Fe}^{+2} \mathrm{Fe}^{+3} \mathrm{O}_{4}\right)$ which involves a weight gain (Fig. 7). The DSC shoulder effect at $960{ }^{\circ} \mathrm{C}$, which is clearly recorded on DDSC curve, was related to the incongruent melting point of the acmite with separation of hematite $[57,58]$. The endothermic peak observed at $1064{ }^{\circ} \mathrm{C}$ in the DDSC curve indicated that cristobalite is being dissolved by the liquid [20]. Indeed, at $1100{ }^{\circ} \mathrm{C}$ the final minerals products detected by PXRD were mainly hematite (33-0664 JCPDS card.) while cristobalite (02-0278 JCPDS card) is evidently in a small amount because its reflections are close to the detection limit (Fig. 8).

The structural changes of crocidolite with increasing temperature can be summarized in the following steps: dehydrogenation and/or dehydroxylation accompanied by iron oxidation, structure collapse and crystallization of newly formed crystalline phases, early melting. Crocidolite, blue at room temperature, turned into dark red at $1100^{\circ} \mathrm{C}$, mostly due to hematite formation.

At SEM, the raw fibres of crocidolite appear as straight and rigid, looking like needles (Fig. 9a). After heating at $1100{ }^{\circ} \mathrm{C}$, the original morphology is strongly altered (Fig. 9b). The single fibres, originally arranged in fibre bundles (Fig. 9a), now appear as thick sticks, confirming that partial melting occurred during heating. However, it is still possible to recognize some fibrous-like structure that was melt-bonded (Fig. 9b). At higher magnification (HM) crocidolite showed meltfragments composed of an aggregate of particles with totally different morphology with respect to the original morphology (Fig. 9c).

\section{Tremolite}

DSC curve of tremolite asbestos from Val d'Ala (Fig. 10) exhibits a number of both endothermic and exothermic peaks in the range $500-1100{ }^{\circ} \mathrm{C}$ that can be explained by the presence of impurities in the sample [59]. The endothermic events at $729{ }^{\circ} \mathrm{C}$ and $776{ }^{\circ} \mathrm{C}$ are due to the dehydroxylation of minor chlorite and antigorite, respectively [37, 36] (see Fig. 10 and Table 3). The exothermic peak at $842{ }^{\circ} \mathrm{C}$ was related to oxidation of $\mathrm{Fe}^{2+}[60]$ present in the chlorite, its presence being also proved by the weight gain in the DTG curve. The exothermic effect at $898{ }^{\circ} \mathrm{C}$ is interpreted as 
recrystallization to forsterite and hematite. The shoulder at $955^{\circ} \mathrm{C}$ on DSC curve was ascribed to talc breakdown [38], while the sharp endothermic peak at $1046{ }^{\circ} \mathrm{C}$ corresponds to breakdown of tremolite in agreement with Luckewicz [61]. The main TG weight loss of $2.02 \%$ between 850 and $1050{ }^{\circ} \mathrm{C}$ due to the tremolite dehydroxylation (Fig. 10, Table 2) was in agreement with the theoretical tremolite water content [62]. Finally, the exothermic DSC signal at $1077{ }^{\circ} \mathrm{C}$ was related to the crystallization of diopside. The effect on TG curve $(-0.17 \mathrm{wt} \%)$ below $110{ }^{\circ} \mathrm{C}$ was ascribed to the release of humidity adsorbed at the sample surface. The mineral products after heating to 1100 ${ }^{\circ} \mathrm{C}$ were diopside (JCPDS card 11-0654), forsterite and hematite deriving from tremolite and chlorite breakdown (Fig. 8).

Figure 9d depicts the typical morphology of tremolite fibres; they are stiff and exhibit a prismatic rod shaped morphology. After thermal treatment, the crystal habit is preserved but almost all the individuals result more brittle and fractured nearly perpendicular to the fibre axis (Fig. 9e). The HM Fig. 9f depicts the presence of newly-formed polyhedral crystals on the surface of the pristine tremolite asbestos some of which exhibit definite morphology with clear evidence of edges and faces. The growth occurs through the formation of recrystallizing-islands with heterogeneous lens shape. On the surface of the pristine tremolite asbestos the growth and coalescence of the recrystallizing-islands evolve from lens to faceted crystals. EDS/SEM investigations confirmed that the pseudomorphic process involves a complete recrystallization of the original tremolite asbestos into diopside.

\section{Amosite}

Characteristic DSC/TG thermogram of amosite is presented in Fig. 11. The first DSC weak peak at $288{ }^{\circ} \mathrm{C}$ is caused by the breakdown of goethite [63] present as impurity which transforms into hematite [64]. The second broad endothermic effect at $741{ }^{\circ} \mathrm{C}$ (Fig. 11) was related to the structural breakdown of amosite (Table 3), although amosite decomposition started at $600{ }^{\circ} \mathrm{C}$ with the formation of oxy-amosite $[23,26]$ and ended at about $850{ }^{\circ} \mathrm{C}$ in agreement with the literature data 
$[22,23,27]$. Finally, the DSC curve shows a broad exothermic peak at $878{ }^{\circ} \mathrm{C}$ due to enstatite and

hematite formation, as confirmed by the PXRD pattern (Fig. 12). The very weak endothermic effect in the range $530-580{ }^{\circ} \mathrm{C}$ (Fig. 11), evidenced in the DDSC curve, could be due to the structural $\alpha \rightarrow \beta$ transition of quartz [65] which is present in the sample as impurity (Fig. 12).

The TG curve of amosite showed a continuous weight loss of $1.94 \%$ between 110 and $690{ }^{\circ} \mathrm{C}$, due to dehydroxylation and dehydrogenation reactions $[21,26]$ which involve a weight gain of $0.24 \%$ between 690 and $1000{ }^{\circ} \mathrm{C}$, due to oxidation of ferrous iron (Fig. 11). In fact, hematite (JCPDS card 24-0072 ) was also found among the final mineral products (Fig. 12) in addition to enstatite (JCPDS card 07-0216) and quartz (JCPDS card 07-0346). The effect on TG curve (-0.33 wt\%) below 110 ${ }^{\circ} \mathrm{C}$ was ascribed to the release of humidity adsorbed at the sample surface.

Raw amosite (Fig. 13a) shows fibres which look like flexible needle arranged in bundles. After heating at $1100{ }^{\circ} \mathrm{C}$, the newly-formed silicate (enstatite) preserved the original fibrous morphology (pseudo-morphosis) but fibres appear more rigid and thicker (Fig. 13b). In some cases, single fibres seem to be fused together at forming prismatic crystal (Fig. 13b, 13c) and when observed at higher magnification, they appear partially covered by pseudo-spherical particles growing along the axial direction of the fibres (Fig. 13c).

\section{Anthophyllite asbestos}

Figure 14 presents the thermal behaviour of anthophyllite asbestos. DTG curve shows one main peak of maximum weight loss $(2.30 \%)$ at $868{ }^{\circ} \mathrm{C}$ due to anthophyllite dehydroxylation in correspondence with the shoulder at $824{ }^{\circ} \mathrm{C}$ on DSC curve. However, DDSC confirm the presence of an endothermic peak at $861{ }^{\circ} \mathrm{C}$ which corresponds to the structural breakdown of this phase [22, 27] followed by recrystallization of enstatite as showed by the exothermic peak at $915{ }^{\circ} \mathrm{C}$ (Fig. 14). According to Freeman [27] the decomposition temperatures of anthophyllite asbestos as well as tremolite asbestos were higher than those reported for amosite and crocidolite. The weak endothermic peaks at 246 and $509^{\circ} \mathrm{C}$ (Fig. 14) should be due to the dehydration and 
dehydroxylation of vermiculite [66]. The DTG peaks at 972 and $1004{ }^{\circ} \mathrm{C}$ (Fig. 14) are interpreted as the dehydroxylation of talc [38] and biotite [67] respectively, present as impurities. PXRD of anthophyllite asbestos after heating to $1100{ }^{\circ} \mathrm{C}$ (Fig. 12) exhibits the lines of enstatite (02-0520 JCPDS card.) and cristobalite (03-0267 JCPDS card).

Fibres of anthophyllite asbestos appear straight, poorly flexible and thin and exhibit a slender needle-like crystal habit both before and after heating treatment (Fig. 13d, 13e). SEM images collected at higher magnification (Fig. 13f) showed that the new phase formed after heating (enstatite) preserves the original fibre morphology (pseudomorphosis) but the surface becomes rough.

\section{Fibrous erionite}

The TG curve of Fig. 15 showed a continuous weight loss due to the dehydration of erionite $\left(\mathrm{H}_{2} \mathrm{O}\right.$ loss of $17.00 \mathrm{wt} \%$ ), corresponding to the broad endothermic peak at $126^{\circ} \mathrm{C}$ [29] and to the weak endothermic peak at $356{ }^{\circ} \mathrm{C}$ (Table 3) on the DSC curve. In the first endothermic effect, the water loss is $16.11 \mathrm{wt} \%$ while in the second endothermic the water loss is $0.89 \mathrm{wt} \%$. The complete dehydration is attained at $450{ }^{\circ} \mathrm{C}$ [68] without loss of crystallinity which started at temperature above $700{ }^{\circ} \mathrm{C}$ (as verified by PXRD) followed by recrystallization of K-feldspars and plagioclase as evidenced by the DSC exothermic peak at $911^{\circ} \mathrm{C}$ (Fig. 15). The curves are in agreement with those reported in Gottardi and Galli [69] and the estimated temperature of breakdown and recrystallization is comparable to that $\left(840^{\circ} \mathrm{C}\right)$ reported by Ballirano and Cametti [70]. Differences may be related not only to different experimental conditions but also to different $\mathrm{Si} / \mathrm{Al}$ ratio, ionic potential and size of exchangeable cations [19], and crystallite size of the various samples [70]. The products of erionite recrystallization after heating to $1000{ }^{\circ} \mathrm{C}$ were $\mathrm{K}$-feldspar, plagioclase and quartz (see the PXRD in Fig. 16), according to the reaction sequence $\mathrm{Na}_{5} \mathrm{~K}_{3} \mathrm{Al}_{8} \mathrm{Si}_{28} \mathrm{O}_{72} \cdot 28 \mathrm{H}_{2} \mathrm{O}$ (approximated erionite formula) $\rightarrow \mathrm{Na}_{5} \mathrm{~K}_{3} \mathrm{Al}_{8} \mathrm{Si}_{28} \mathrm{O}_{72} \rightarrow 3 \mathrm{KAlSi}_{3} \mathrm{O}_{8}+5 \mathrm{NaAlSi}_{3} \mathrm{O}_{8}+4 \mathrm{SiO}_{2}$ 
At the SEM observation, erionite displays bundles composed of many fibres resembling amphibole

fibres morphology (stubby prismatic and acicular crystals) (Fig. 17a). After heating treatment the new forms have feldspar-like composition as detected by EDS/SEM analyses. At low magnification SEM, imaging show that the fibres are shorter but the original fibrous morphology is preserved (Fig. 17b) and the surface is smooth. However, at higher magnification (Fig. 17c) the surface of the fibrous crystals show irregularities and appear as rather rough (Fig. 17c).

\section{Conclusions}

Thermal decomposition of eight selected mineral fibres (chrysotile, four amphibole asbestos species and erionite) has been investigated using DSC/TG supplemented by PXRD and SEM/EDS. These investigations have shown that the decomposition of UICC chrysotile from Canada occurs at $633{ }^{\circ} \mathrm{C}$ while the structure breakdown for both chrysotile from Val Malenco and from Balangero shift versus higher temperatures taking place at $652{ }^{\circ} \mathrm{C}$ and $660^{\circ} \mathrm{C}$ respectively. The decomposition of chrysotile is followed by the recrystallization into forsterite at about $822{ }^{\circ} \mathrm{C}$. As it concerns amphiboles, the breakdown of crocidolite, amosite, anthophyllite asbestos and tremolite asbestos ranged from 850 to $1046{ }^{\circ} \mathrm{C}$. Crocidolite asbestos UICC is decomposed at around $850{ }^{\circ} \mathrm{C}$ with the formation of magnetite, cristobalite and acmite. However, at $1100{ }^{\circ} \mathrm{C}$ the final minerals products were mainly hematite and partially melted cristobalite. Amosite UICC decomposes into enstatite and hematite at $878{ }^{\circ} \mathrm{C}$. Anthophyllite asbestos UICC breakdown leads to the formation of enstatite and cristobalite at $861{ }^{\circ} \mathrm{C}$. The breakdown of tremolite asbestos occurs at $1046{ }^{\circ} \mathrm{C}$ with the consequent formation of diopside.

While for tremolite and anthophyllite asbestos the complete dehydroxylation occurs in one main effect $\left(1046{ }^{\circ} \mathrm{C}\right.$ and $861{ }^{\circ} \mathrm{C}$ respectively) and leads to the breakdown of the mineral structure, the dehydroxylation of amosite and crocidolite occurs in various steps in the temperature range 570 $850{ }^{\circ} \mathrm{C}$ and it does not correspond with the structural collapse. Fibrous erionite shows the same 
behaviour as that reported for amosite and crocidolite: although the complete dehydroxylation took

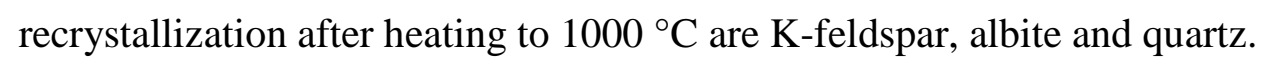

Despite the thermal treatment, all fibrous samples preserve the same external fibrous habit but the structure is completely changed at a molecular scale: this phenomenon called pseudomorphosis lead to the complete transformation of asbestos minerals into non-hazardous silicates such as forsterite and enstatite. However, potentially hazardous minor phases such as cristobalite and quartz were found in the new phases appeared after thermal treatment of anthophyllite asbestos, crocidolite and asbestiform erionite; these may hinder a safe reuse of the processed asbestos samples.

Moreover, it has been demonstrated that DSC and DTG analyses are very effective for the identification of minerals impurities both in chrysotile, amphibole asbestos and asbestiform erionite specimens. Indeed, DSC and DTG analysis clearly showed the presence of low impurities, not relievable by the semi-quantitative PXRD analysis, such as pyroaurite, talc, brucite, smectite, dolomite, siderite, goethite, and biotite. However, all identified minerals are non-fibrous, mostly having platy morphology.

The knowledge of the thermal behaviour of the eight fibrous samples studied in this work will allow interpret thermograms obtained from natural samples and asbestos treated by heating with more confidence.

\section{References}


1. Guthrie GD, Mossman BT. Merging the Geological and Biological Science an Integrated Approach to Mineral Induced Pulmonary Disease. In Guthrie GD, Mossman BT, editors. Health Effects of Mineral Dusts, Vol. 28, Reviews in Mineralogy \& Geochemistry. Chelsea, MI: Mineralogical Soc. America Geochemical Soc; 1993. pp. 1-5.

2. Francine B, Ambrosi JP, Carbone M. Asbestos is not just asbestos: an unrecognised health hazard. The lancet oncol. 2013; 14.7: 576-8.

3. Whittaker EJW. The structure of chrysotile. V. Diffuse reflections and fibre texture. Acta Crystallogr. 1957;10:149-56.

4. Yada K. Study of microstructure of chrysotile asbestos by high-resolution electron microscopy. Acta Crystallogr. 1971;A 27:659-64.

5. Smith JV, Bennett JM. Enumeration of 4-connected 3-dimensional nets and classification of framework silicates; the infinite set of ABC-6 nets; the Archimedean and sigma-related nets. Am Mineral. 1981;66: 777-88.

6. Gualtieri G, Artioli E, Passaglia S, Bigi A, Viani JCH. Crystal structure-crystal chemistry relationships in the zeolites erionite and offretite, Am Mineral. 1998;83:590-606.

7. Gunter ME, Belluso E, Mottana A. Amphiboles: environmental and health concerns. In: Rosso JJ editor. Reviews in Mineralogy and Geochemistry. Chantilly, VA: Mineralogical Society of America Geochemical Society; 2007. pp. 453-516.

8. Kamp DW. Asbestos-induced lung diseases: an update. Transl Res. 2009;153:143-52. 
9. Bertino P, Marconi A, Palumbo 1, Bruni BM, Barbone D, Germano S, Dogan AU, Tassi GF, Porta C, Mutti 1, Gaudino G. Erionite. Asbestos differently cause transformation of human mesothelial cells. Int J Cancer. 2007;121:2766-74.

10. Plescia P, Gizzi D, Benedetti S, Camilucci L, Fanizza C, De Simone P, Paglietti F. Mechanochemical treatment to recycling asbestos-containing waste. Waste Manage. 2003;23:209_ 18.

11. Favero-Longo SE, Castelli D, Fubini B, Piervittori R. Lichens on asbestos-cement roofs: Bioweathering and biocovering effects. J Hazard Mater. 2009;162:1300-8.

12. Anastasiadou K. Axiotis D, Gidarakos E. Hydrothermal conversion of chrysotile asbestos using near supercritical conditions. J. Hazard. Mater. 2010;179:926-32.

13. Leonelli C, Veronesi P, Boccaccini DN, Rivasi MR, Barbieri L, Andreola F, Lancellotti I, Rabitti D, Pellacani GC. Microwave thermal inertisation of asbestos containing waste and its recycling in traditional ceramics. J Hazard Mater. 2006;135:149-55.

14. Boccaccini DN, Leonelli C, Rivasi MR, Romagnoli M, Veronesi P, Pellacani GC, Boccaccini AR. Recycling of microwave inertised asbestos containing waste in refractory materials. J Eur Ceram. Soc. 2007;27:1855-8.

15. Candela PA, Crummett CD, Earnest DJ, Frank MR, Wylie AG. Low-pressure decomposition of chrysotile as a function of time and temperature. Am Mineral. 2007;92:1704-13.

16. Gualtieri AF, Cavenati C, Zanatto I, Meloni M, Elmi G, Lassinantti Gualtieri M. The transformation sequence of cement-asbestos slates up to $1200^{\circ} \mathrm{C}$ and safe recycling of the reaction product in stoneware tile mixtures. J Hazard Mater. 2008,152:563-70. 
17. Dellisanti F, Rossi PL, Valdre` G. Remediation of Asbestos Containing Materials by Joule heating vitrification performed in a pre-pilot apparatus. Int J Miner Process. 2009;91:61-7.

18. Yvon Y, Sharrock P. Characterization of thermochemical inactivation of Asbestos Containing Wastes and recycling the mineral residues in cement products. Waste Biomass Valor. 2011;2:16981.

19. Cattaneo A, Gualtieri AF, Artioli G. Kinetic study of the dehydroxylation of chrysotile asbestos with temperature by in situ XRPD. Phys Chem Miner. 2003;30:177-83.

20. Hodgson AA, Freeman AG, Taylor HFW. The thermal decomposition of crocidolite from Koegas, South Africa. Miner Mag. 1965;35:5-30.

21. Rouxhet PG, Gillard JL, Fripiat JJ. Thermal decomposition of amosite, crocidolite, and biotite. Mineral Mag. 1972;38:583-92.

22. Kohyama N, Shinohama Y, Suzuki Y. Mineral phases and some re-examined characteristics of the International Union Against Cancer standard asbestos samples. Am J Ind Med. 1996;30:515-28.

23. Jeyaratnam M. West NG. A study of heat-degraded chrysotile, amosite andcrocidolite by X-ray diffraction, Ann Occup Hyg. 1994;38:137-48.

24. Gualtieri AF, Levy D, Belluso E, Dapiaggi M. Kinetics of the decomposition of crocidolite asbestos: a preliminary real-time X-ray powder diffraction study. Miner Sci Forum. 2004;443-444: $291-4$. 
25. Kusiorowski R, Zaremba T, Gerle A, Piotrowski J, Simka W, Adamek J. Study on the thermal decomposition of crocidolite asbestos. J Therm Anal Calorim. 2015. doi: 10.1007/s10973-0154421-7.

26. Hodgson AA, Freeman AG, Taylor HFW. The thermal decomposition of amosite. Miner Mag. 1965;35:445-63.

27. Freeman AG. The dehydroxylation behavior of amphibole. Miner Mag. 1966;35:953-7.

28. Kusiorowski R, Zaremba T, Piotrowski J, Adamek J. Thermal decomposition of different types of asbestos. J Therm Anal Calorim. 2012;109: 693-704.

29. Papke, KG. Erionite and associated zeolites in Nevada. Nev Bur Mines Geol Bull. 1972;79:131.

30. Pugnaloni A, Giantomassi F, Lucarini G, Capella S, Bloise A, Di Primio R, Belluso E. (2013) Cytotoxicity induced by exposure to natural and synthetic tremolite asbestos: an in vitro pilot study. Acta Histochem. 2013;115:100-12.

31. Duncan KE, Cook PM, Gavett SH, Dailey LA, Mahoney RK, Ghio AJ, Roggli VL, Devlin RB. In vitro determinants of asbestos fiber toxicity: Effect on the relative toxicity of Libby amphibole in primary human airway epithelial cells. Part Fibre Toxicol. 2014;11:1-14.

32. Pollastri S, Gualtieri AF, Lassinantti Gualtieri M, Hanuskova M, Cavallo A, Gaudino G. The zeta potential of mineral fibres. J Hazard Mater. 2014; 276:469-79.

33. Frost RL, Erickson KL. Thermal decomposition of synthetic hydrotalcites reevesite and pyroaurite. J Therm Anal Calorim. 2004;76: 217-25. 
34. Kissinger HE. Reaction kinetics in differential thermal analysis. Anal Chem. 1957;29:1702-6.

35. Gallagher PK, Warne SStJ. Thermomagnetometry and thermal decomposition of siderite. Thermochim Acta. 1981;43: 253-67.

36. Viti C. Serpentine minerals discrimination by thermal analysis. Am Mineral. 2010;95:631-8.

37. Villieras F, Yvon J, Cases JM, De Donato P, Lhote F, Baeza R. Development of microporosity in clinochlore upon heating. Clay Clay Miner. 1994;42: 679-88.

38. Catalano M, Belluso E. Miriello D, Barrese E, Bloise A. Synthesis of Zn-doped talc in hydrothermal atmosphere. Cryst Res Technol. 2014;49:283-9, 2014.

39. Ball MC, Taylor HFW. The dehydration of chrysotile in air and under hydrothermal conditions. Mineral Mag. 196;33:467-82.

40. Brindley GW, Hayami R. Mechanism of formation of forsterite and enstatite from serpentine. Mineral Mag. 1965;35:189-95.

41. Martin CJ. The thermal decomposition of chrysotile. Mineral Mag. 1977;41:453-9.

42. MacKenzie KJD, Meinhold RH. Thermal reactions of chrysotile re $7 v i s e d:$ A 29Si and $25 \mathrm{Mg}$ MAS NMR study. Am Mineral. 1994;79:43-50.

43. Bloise A, Belluso E, Barrese E, Miriello D, Apollaro C. Synthesis of Fe-doped chrysotile and characterization of the resulting chrysotile fibers. Cryst Res Technol. 2009;44:590-6. 
44. Bloise A, Belluso E, Fornero E, Rinaudo C, Barrese E, Capella S. Influence of synthesis conditions on growth of Ni-doped chrysotile. Micropor Mesopor Mat. 2010;132:239-45.

45. Gunasekaran S, Anbalagan G. Thermal decomposition of natural dolomite. B Mater Sci. 2007;30:339-44.

46. Bloise A, Critelli T, Catalano M, Apollaro C, Miriello D, Croce A, Barrese E, Liberi F, Piluso E, Rinaudo C, Belluso E. Asbestos and other fibrous minerals contained in the serpentinites of the Gimigliano-Mount Reventino Unit (Calabria, S-Italy). Environ Earth Sci. 2014;71:3773-86.

47. Viti C, Giacobbe C, Gualtieri AF. Quantitative determination in massive serpentinites using DTA: implications for asbestos determination, Am Miner. 2011;96:1003-11.

48. Cattaneo A, Somigliana A, Gemmi M, Bernabeo F, Savoca D, Cavallo DM, Bertazzi PA. Airborne Concentrations of Chrysotile Asbestos in Serpentine Quarries and Stone Processing Facilities in Valmalenco, Italy. Ann Occup Hyg. 2012; 1-13.

49. Lesci IG, Balducci G, Pierini F, Soavi F, Roveri N. Surface features and thermal stability of mesoporous Fe doped geoinspired synthetic chrysotile nanotubes. Micropor Mesopor Mat. 2014;197:8-16.

50. Lafay R, Montes-Hernandez G, Janots E, Auzende AL, Chiriac R, Lemarchand D, Toche F. Influence of trace elements on the textural properties of synthetic chrysotile: Complementary insights from macroscopic and nanoscopic measurements. Micropor Mesopor Mat. 2014;183:8190. 
51. Wypych F, Schreiner WH, Mattoso N,. Mosca DH, Marangonia R, Bento CAS. Covalent grafting of phenylphosphonate groups onto layered silica derived from in situ-leached chrysotile fibers. J Mater Chem. 2003;13:304-7.

52. Giacobbe C, Gualtieri AF, Quartieri S, Rinaudo C, Allegrina M, Andreozzi GB. Spectroscopic study of the product of thermal transformation on Chrysotile-Asbestos Containing Materials. Eur J Mineral. 2010;22:535-46.

53. Croce A, Allegrina M, Trivero P, Rinaudo C, Viani A, Pollastri S, Gualtieri AF. The concept of 'end of waste' and recycling of hazardous materials: in depth characterization of the product of thermal transformation of cement-asbestos. Mineral Mag. 2014;78:1177-91.

54. Fujishige M, Kuribara A, Karasawa I, Kojima A. Low-temperature pyrolysis of crocidolite and amosite using calcium salts as a flux. J Ceram Soc Jpn. 2007;115:434-9.

55. Addison CC, Addison WE, Neal GA, Sftarv JH. Amphiboles Part I: The oxidation of crocidolite. Journ Chem Soc. 1962;278:1468-71.

56. Brindley GW, Youell RF. Ferrous chamosite and ferric chamosite. Min Mag. 1953;30:57-70.

57. Yagi K. The system acmite-diopside and its bearing on the stability relations of natural pyroxenes of the acmite-hedenbergite-diopside series. Am Mineral. 1966;51:976-1000.

58. Bowen NL, Schairer JF. The fusion relations of acmite. Amer J Sci ser 5. 1929;18:365-74.

59. MacKenzie RC. The differential thermal investigation of clays. London: Mineralogical Society (Clay Minerals Group); 1957.

60. Jones AA. Charges on the surfaces of two chlorites. Clay Miner. 1981;16:347-59. 
61. Luckewicz W. Differencial thermal analysis of chrysotile asbestos in pure talc and talc containing other minerals. J Soc Cosmet Chem. 1975;26:431-437.

62. Bloise A, Fornero E, Belluso E, Barrese E, Rinaudo C. Synthesis and characterization of tremolite asbestos fibres. Eur J Mineral. 2008;20:1027-33.

63. Gualtieri AF, Venturelli P. In situ study of the goethite-hematite phase transformation by real time synchrotron powder diffraction. Am Mineral. 1999;84:895-904.

64. Miriello D, Bloise A, De Francesco A, Crisci GM, Chiaravalloti F, Barca D, La Russa MF, Marasco E. Colour and composition of nodules from the Calabrian clay deposits: a possible raw material for pigments production in Magna Graecia. Period Mineral. 2010;79:59-69.

65. Moore GSM, Rose HE. The structure of powdered quartz. Nature. 1973;242:187-90.

66. Brydon JE, Turner RC. The nature of Kenya vermiculite and its aluminum hydroxide complexes. Clays Clay Miner. 1972;20:1-11.

67. Bagin VI, Gendler TS, Dainyak LG, Kuz'min RN. Mossbauer, thermomagnetic, and x-ray study of cation ordering and high-temperature decomposition in biotite. Clays Clay Miner. 1980;28:18896.

68. Ballirano P, Andreozzi GB, Dogan M, Dogan AU. Crystal structure and iron topochemistry of erionite-K from Rome, Oregon, U.S.A. Am Mineral. 2009;94:1262-70.

69. Gottardi G, Galli E. Natural zeolites. Berlin: Springer-Verlag; 1985. 
70. Ballirano P, Cametti G. Dehydration dynamics and thermal stability of erionite-K:

1

2

3

4

5

6

7

8

9

10

11

12

13

14

15

16

17

18

19

20

21

22

23

24

25

26

27

28

29

30

31

32

33

34

35

36

37

38

39

40

41

42

43

44

45

46

47

48

49

50

51

52

53

54

55

56

57

58

59

60

61

62

63

64

65

Experimental evidence of the "internal ionic exchange" mechanism. Micropor Mesopor Mat. 2012;163:160-8. 
1

2

\begin{tabular}{|c|c|c|}
\hline Sample & Calculated chemical formula & Provenance \\
\hline Chrysotile UICC & $\left(\mathrm{Mg}_{5.93} \mathrm{Fe}^{2+}{ }_{0.04} \mathrm{Al}_{0.02} \mathrm{Fe}^{3+}{ }_{0.08}\right)_{6.07} \mathrm{Si}_{4.03} \mathrm{O}_{10}(\mathrm{OH})_{7.66}$ & Quebec (Canada) ${ }^{a *}$ \\
\hline Chr Balangero & $\left(\mathrm{Mg}_{5.81} \mathrm{Fe}^{2+}{ }_{0.15} \mathrm{Al}_{0.27} \mathrm{Fe}^{3+}{ }_{0.09} \mathrm{Cr}_{0.01}\right)_{6.33} \mathrm{Si}_{3.97} \mathrm{O}_{10}(\mathrm{OH})_{7.11}$ & Val Malenco, Sondrio (Italy) \\
\hline Chr Val Malenco & $\left(\mathrm{Mg}_{5.85} \mathrm{Fe}^{2+}{ }_{0.06} \mathrm{Al}_{0.02} \mathrm{Fe}^{3+}{ }_{0.05} \mathrm{Ni}_{0.01}\right)_{5.99} \mathrm{Si}_{4.01} \mathrm{O}_{10}(\mathrm{OH})_{7.86}$ & Balangero, Turin (Italy) \\
\hline Amosite & $\left(\mathrm{Ca} 0.02 \mathrm{Na}{ }_{0.01}\right)\left(\mathrm{Fe}^{2+}{ }_{5.36} \mathrm{Mg}_{1.48} \mathrm{Fe}^{3+}{ }_{0.11} \mathrm{Mn}_{0.06}\right){ }_{7.01}\left(\mathrm{Si}_{7.93} \mathrm{Al}_{0.01}\right)_{7.94} \mathrm{O}_{21.94}(\mathrm{OH})_{2.06}$ & Penge mine, Northern Province (South Africa) ${ }^{8}$ \\
\hline Anthophyllite & $\mathrm{Ca}_{0.04}\left(\mathrm{Mg}_{5.81} \mathrm{Fe}^{2+}{ }_{0.92} \mathrm{Fe}^{3+}{ }_{0.21} \mathrm{Mn}_{0.04}\right)_{6.98}\left(\mathrm{Si}_{7.83} \mathrm{Al}_{0.02}\right)_{7.85} \mathrm{O}_{21.63}(\mathrm{OH})_{2.37}$ & Paakkila mine, Paakkila (Finland) ${ }^{+}$ \\
\hline Crocidolite & $\left(\mathrm{Na}_{1.96} \mathrm{Ca}_{0.03} \mathrm{~K}_{0.01}\right)_{2}\left(\mathrm{Fe}^{2+}{ }_{2.34} \mathrm{Fe}^{3+}{ }_{2.05} \mathrm{Mg}_{0.52}\right)_{4.91}\left(\mathrm{Si}_{7.84} \mathrm{Al}_{0.02}\right)_{7.86} \mathrm{O}_{21.36}(\mathrm{OH})_{2.64}$ & Koegas Mine, Northern Cape (South Africa) ${ }^{\#}$ \\
\hline Tremolite & $\left(\mathrm{Ca}_{1.91} \mathrm{Na}_{0.06} \mathrm{~K}_{0.01}\right)_{1.98}\left(\mathrm{Mg}_{4.71} \mathrm{Fe}^{2+}{ }_{0.22} \mathrm{Fe}^{3+}{ }_{0.08} \mathrm{Mn}_{0.02}\right)_{5.03}\left(\mathrm{Si}_{8.01} \mathrm{Al}_{0.02}\right)_{8.03} \mathrm{O}_{22.14}(\mathrm{OH})_{1.86}$ & Val d'Ala, Turin (Italy) \\
\hline Erionite & $\left(\mathrm{Na}_{5.35} \mathrm{~K}_{2.19} \mathrm{Ca}_{0.15} \mathrm{Mg}_{0.11} \mathrm{Ti}_{0.05}\right)_{7.85}\left(\mathrm{Si}_{28.01} \mathrm{Al}_{7.90}\right)_{35.91} \mathrm{O}_{72} \cdot 28.13 \mathrm{H}_{2} \mathrm{O}$ & Jersey, Nevada (USA) \\
\hline
\end{tabular}

Table 1 Calculated chemical formulae (After Pollastri et al., 2015 [38]) and details of the investigated minerals fibres. ${ }^{a}$ Mixture of fiber from the firms Bells, Carey, Cassair, Flintkote, Johns-Manville, Lake, Normandie and National, proportioned roughly to represent Canadian production of asbestos products at that time. *UICC standard Chrysotile "B" Canadian NB \#4173-111-1; ${ }^{8}$ UICC standard Amosite from Penge mine South African; ${ }^{+}$UICC standard Anthophyllite Finnish NB \#4173-111-5; "UICC standard Crocidolite South African NB \#4173-111-3 


\begin{tabular}{|c|c|c|c|c|c|}
\hline \multicolumn{2}{|l|}{ Chrysotile from Canada UICC } & \multicolumn{2}{|c|}{ Chrysotile from Balangero } & \multicolumn{2}{|c|}{ Chrysotile from Val Malenco } \\
\hline T range $\left({ }^{\circ} \mathbf{C}\right)$ & TG loss \% & $\mathrm{T}$ range $\left({ }^{\circ} \mathrm{C}\right)$ & TG loss \% & T range $\left({ }^{\circ} \mathrm{C}\right)$ & TG loss \% \\
\hline $25-110$ & 0.91 & $25-110$ & 0.57 & $25-110$ & 0.54 \\
\hline $430-800$ & 12.22 & $430-800$ & 11.80 & $430-800$ & 12.01 \\
\hline tot loss at 1000 & 18.66 & tot loss at 1000 & 14.87 & tot loss at 1000 & 13.35 \\
\hline \multicolumn{2}{|l|}{ Crocidolite from S. Africa UICC } & \multicolumn{2}{|c|}{ Tremolite from Val d'Ala } & \multicolumn{2}{|c|}{ Amosite from Penge UICC } \\
\hline T range $\left({ }^{\circ} \mathrm{C}\right)$ & TG loss \% & T range $\left({ }^{\circ} \mathrm{C}\right)$ & TG loss \% & T range $\left({ }^{\circ} \mathrm{C}\right)$ & TG loss \% \\
\hline $25-110$ & 0.58 & $30-110$ & 0.17 & $25-110$ & 0.33 \\
\hline $110-680$ & 2.18 & $850-1100$ & 2.02 & $110-690$ & 1.94 \\
\hline tot loss at 1100 & 2.76 & tot loss at 1100 & 3.43 & tot loss at 1100 & 2.17 \\
\hline \multicolumn{2}{|l|}{ Anthophyllite from Paakkila UICC } & \multicolumn{2}{|c|}{ Erionite from Nevada } & & \\
\hline T range $\left({ }^{\circ} \mathbf{C}\right)$ & TG loss \% & T range $\left({ }^{\circ} \mathrm{C}\right)$ & TG loss \% & & \\
\hline $25-110$ & 0.11 & & & & \\
\hline $110-690$ & 2.30 & $25-450$ & 17.00 & & \\
\hline tot loss at 1100 & 4.98 & tot loss at 1000 & 17.99 & & \\
\hline
\end{tabular}

Table 2 Main TG data (weight loss \%) 


\begin{tabular}{|c|c|c|c|c|c|c|c|c|}
\hline $\begin{array}{l}\text { DSC } \\
\text { T }\left({ }^{\circ} \mathbf{C}\right)\end{array}$ & $\begin{array}{l}\text { Chrysotile from } \\
\text { Canada UICC }\end{array}$ & $\begin{array}{l}\text { Chrysotile from } \\
\text { Balangero }\end{array}$ & $\begin{array}{l}\text { Chrysotile from } \\
\text { Val Malenco }\end{array}$ & $\begin{array}{l}\text { Crocidolite from } \\
\text { S. Africa UICC }\end{array}$ & $\begin{array}{l}\text { Tremolite from } \\
\text { Val d'Ala }\end{array}$ & $\begin{array}{l}\text { Amosite from } \\
\text { Penge UICC }\end{array}$ & 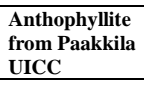 & $\begin{array}{l}\text { Erionite from } \\
\text { Nevada }\end{array}$ \\
\hline & 226 endo $\mathrm{w}$ & & & 320 exo w & & 288 endo & 246 endo $w$ & 126 endo s \\
\hline & 401 endo w & 402 endo & & 354 endo w & & & & 356 endo $w$ \\
\hline & 520 endo $\mathrm{w}$ & & 557 endo $w$ & 431 exo w & & $535 \mathrm{sh}$ & 509 endo $w$ & \\
\hline & 633 endo s & 660 endo $s$ & 652 endo $s$ & 649 endo w & 729 endo s & 741 endo $w$ & $824 \mathrm{sh}$ & \\
\hline & & & & 850 exo & & & & \\
\hline & 823 exo s & 822 exo s & 820 exo s & 928 endo $\mathrm{s}$ & 776 endo w & 878 exo & 915 exo s & 911 exo \\
\hline & & & & $960 \mathrm{sh}$ & $\begin{array}{ll}842 & \text { exo w } \\
898 & \text { exo w } \\
955 & \text { sh }\end{array}$ & & & \\
\hline & & & & $1064 \mathrm{sh}$ & $\begin{array}{l}1046 \text { endo s } \\
1077 \text { exo }\end{array}$ & & & \\
\hline
\end{tabular}

Table 3 Peak temperatures in DSC curves; $w=$ weak, $s=$ strong, $s h=$ shoulder, endo= endothermic, exo = exothermic 
Fig. 1 Thermal analysis of chrysotile UICC from Canada. Solid line: Solid line: DSC. Dashed line: DTG. Dotted line: TG

Fig. 2 PXRD patterns recorded before (b) and after (a) heating at $1000{ }^{\circ} \mathrm{C}$ for the three kinds of chrysotile; from the bottom to top chrysotile UICC $(\mathrm{CCb}$ and $\mathrm{CCa})$; chrysotile from Balangero $(\mathrm{CBb}$ and $\mathrm{CBa})$; chrysotile from Val Malenco (CVMb and CVMa)

Fig. 3 Thermal analysis of chrysotile from Balangero. Solid line: DSC. Dashed line: DTG. Dotted line: TG

Fig. 4 Thermal analysis of chrysotile from Val Malenco. Solid line: DSC. Dashed line: DTG. Dotted line: TG

Fig. 5 Comparison of DSC curves recorded for chrysotile from Balangero (CB), from Val Malenco (CVM) and UICC from Canada (CC)

Fig. 6 Secondary electron SEM images of the three kinds of chrysotile: UICC from Canada, first line; from Balangero, second line; from Val Malenco, third line. From left to right: first column $(\mathbf{a}, \mathbf{d}, \mathbf{g})$, before heating treatment at $1000{ }^{\circ} \mathrm{C}$; second and third column $(\mathbf{b}, \mathbf{c}, \mathbf{e}, \mathbf{f}, \mathbf{h}, \mathbf{i})$, after heating. Images $\mathbf{c}, \mathbf{f}, \mathbf{i}$ acquired with high resolution SEM, testifying the pseudomorphic transformation of the chrysotile fibres with temperature

Fig. 7 Thermal analysis of crocidolite UICC. Solid line: DSC. Dashed line: DTG. Dotted line: TG

Fig. 8 PXRD patterns recorded before $\mathbf{b}$ and after a heating at $1000{ }^{\circ} \mathrm{C}$ of crocidolite UICC (Crb and Cra); tremolite asbestos (Tb and $\mathrm{Ta})$

Fig. 9 Secondary electron SEM images of crocidolite UICC (first line) and tremolite asbestos (second line). From left to right: first column $(\mathbf{a}, \mathbf{d})$, before heating treatment at $1000{ }^{\circ} \mathrm{C}$; second and third column (b, e, c, f), after heating. Images c, $\mathbf{i}$ acquired with high resolution SEM, showing a complete pseudo-morphic recrystallization occurred to fibres. Arrow in $\mathbf{b}$ indicates crocidolite fibres partially melted 
Fig. 10 Thermal analysis of tremolite asbestos from Val d'Ala. Solid line: DSC. Dashed line: DTG. Dotted line: TG

Fig. 11 Thermal analysis of amosite. Solid line: DSC. Dashed line: DTG. Dotted line: TG

Fig. 12 PXRD patterns recorded before $\mathbf{b}$ and after $\mathbf{a}$ heating at $1000{ }^{\circ} \mathrm{C}$ of anthophyllite asbestos UICC (Anb and Ana)

Fig.13 Secondary electron SEM images of amosite (first line) and anthophyllite asbestos UICC (second line). From left to right: first column $(\mathbf{a}, \mathbf{d})$, before heating treatment at $1000{ }^{\circ} \mathrm{C}$; second and third column $(\mathbf{b}, \mathbf{e}, \mathbf{c}, \mathbf{f})$, after heating. High resolution SEM images $\mathbf{c}$ and $\mathbf{i}$ show the fibrous recrystallized forms

Fig. 14 Thermal analysis of anthophyllite asbestos UICC. Solid line: DSC. Dashed line: DTG. Dotted line: TG

Fig. 15 Thermal analysis of asbestiform erionite. Solid line: DSC. Dashed line: DTG. Dotted line: TG

Fig. 16 PXRD patterns from asbestiform erionite before (Erb) and after (Era) heating at $1000{ }^{\circ} \mathrm{C}$

Fig.17 Secondary electron SEM images of asbestiform erionite $\mathbf{a}$ before and $\mathbf{b}, \mathbf{c}$ after; heating treatment at 1000 High resolution SEM Image c shows rough surface 


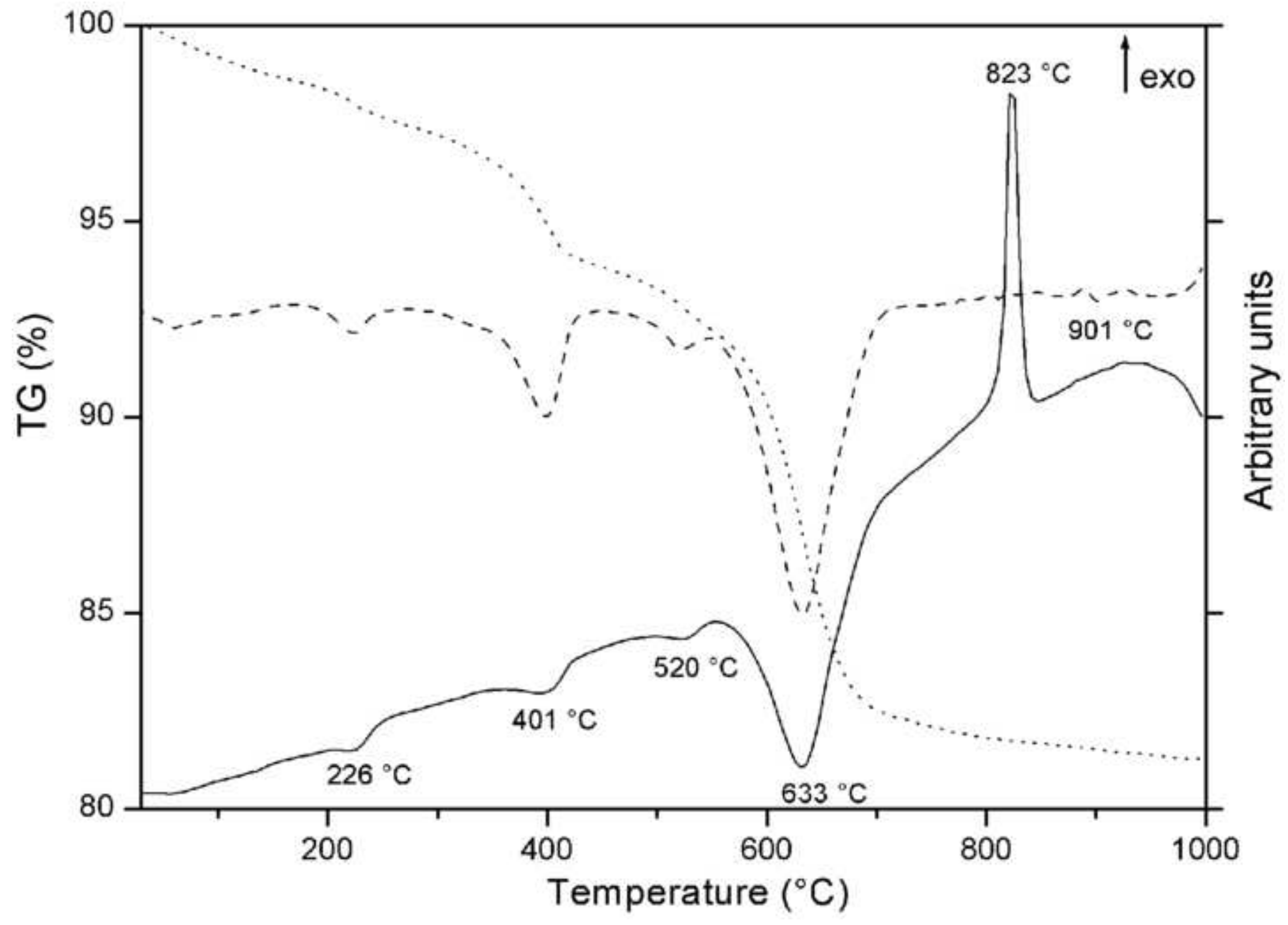




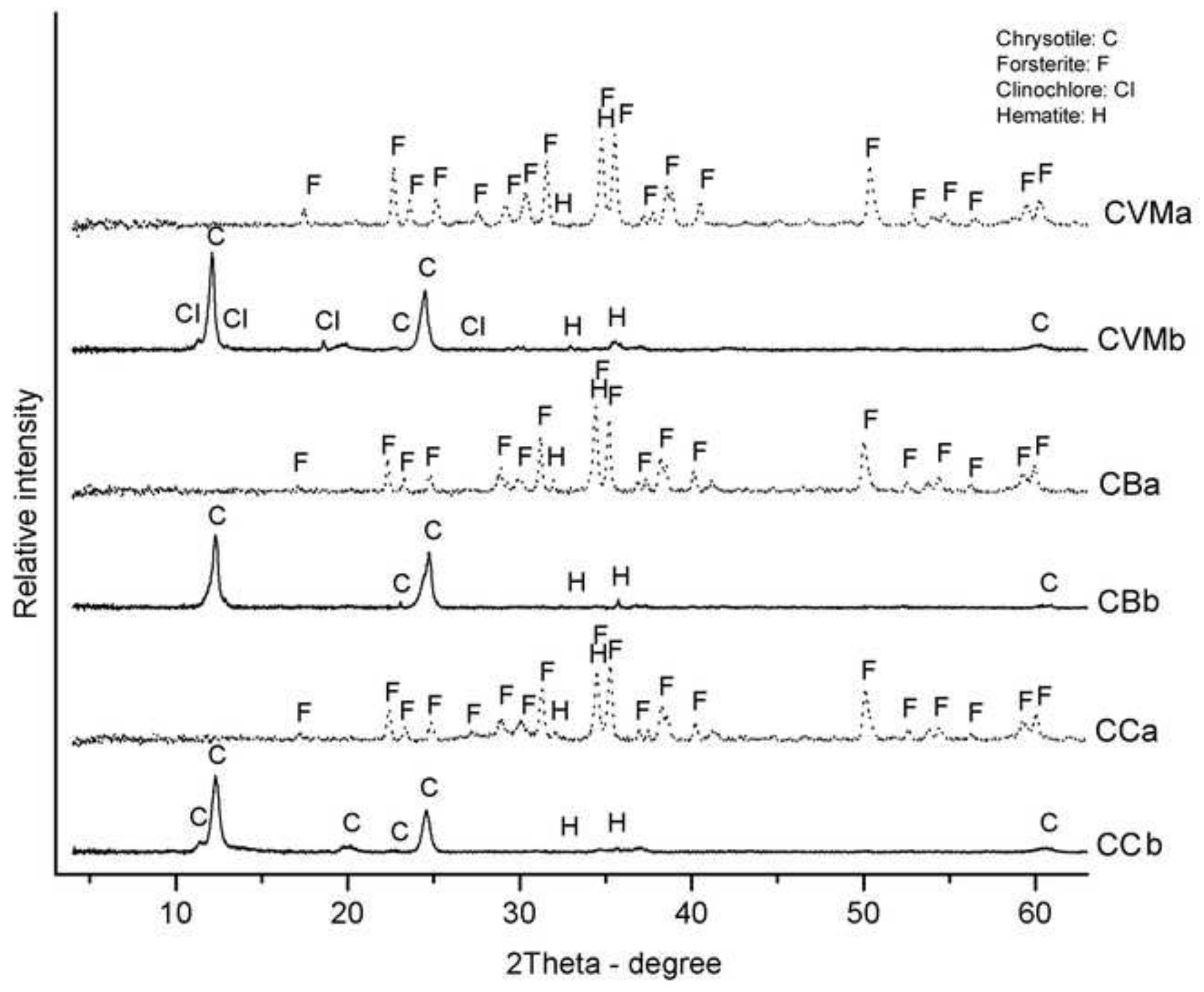




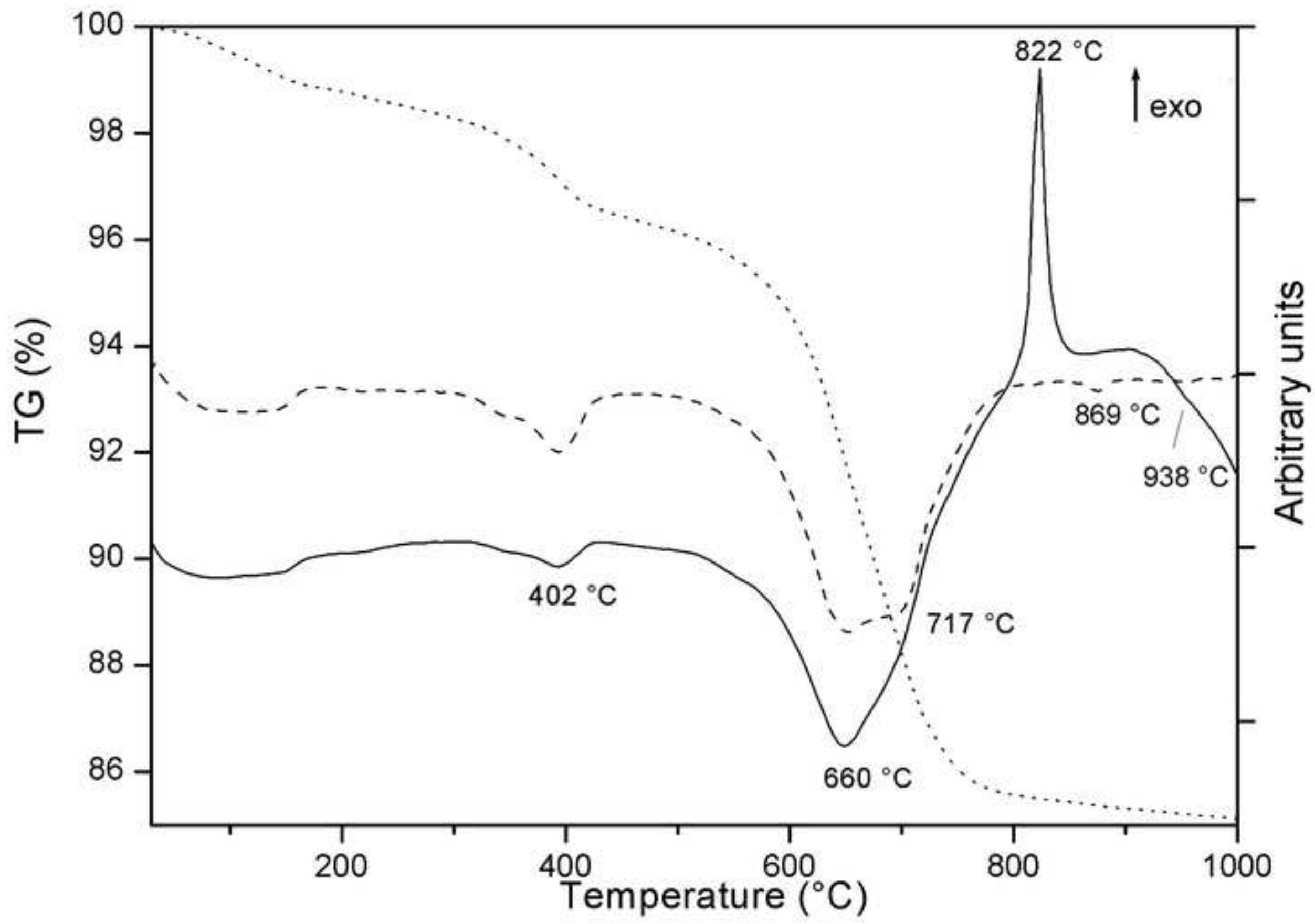


Click here to download Figure: Fig. 4.tif

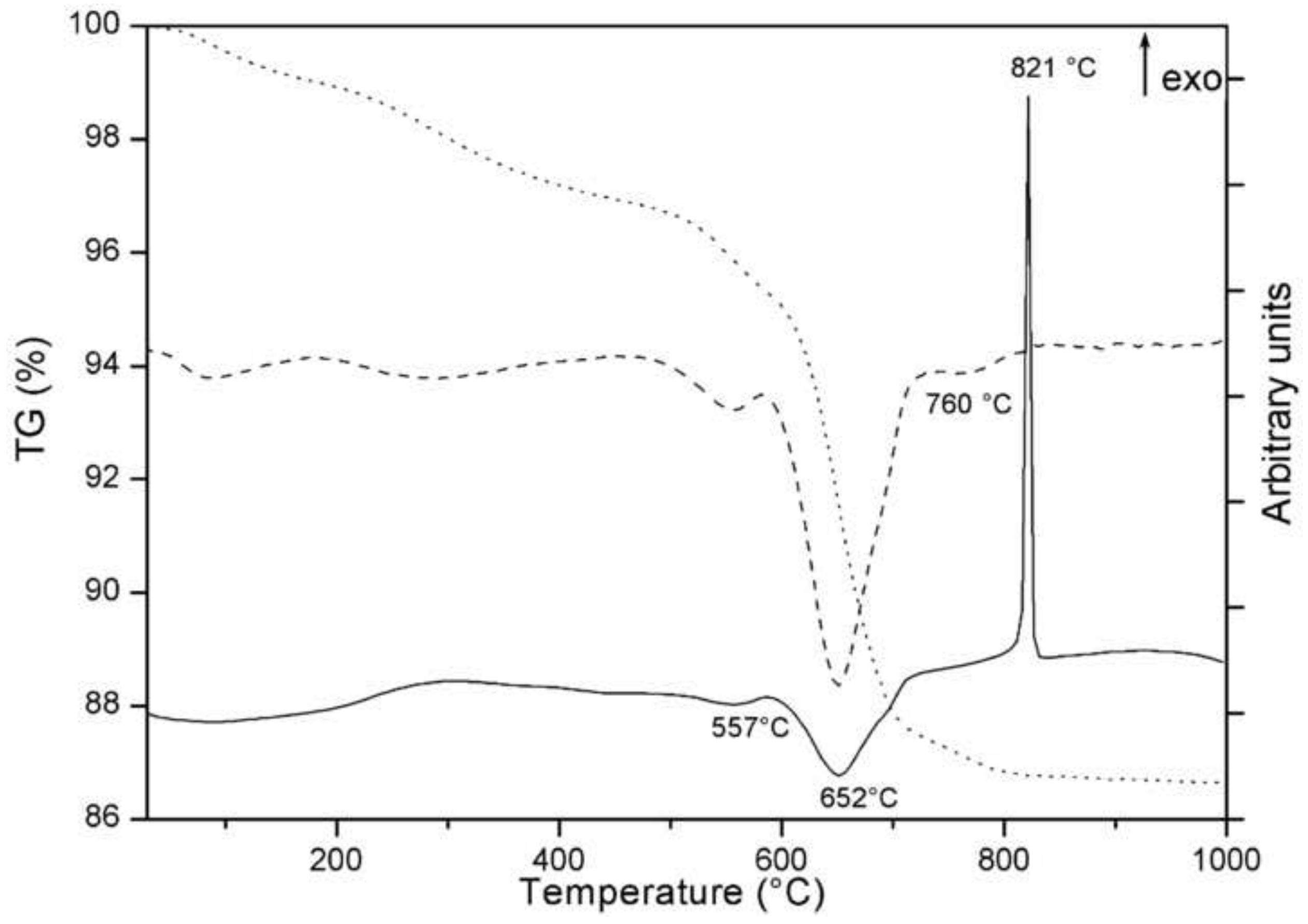




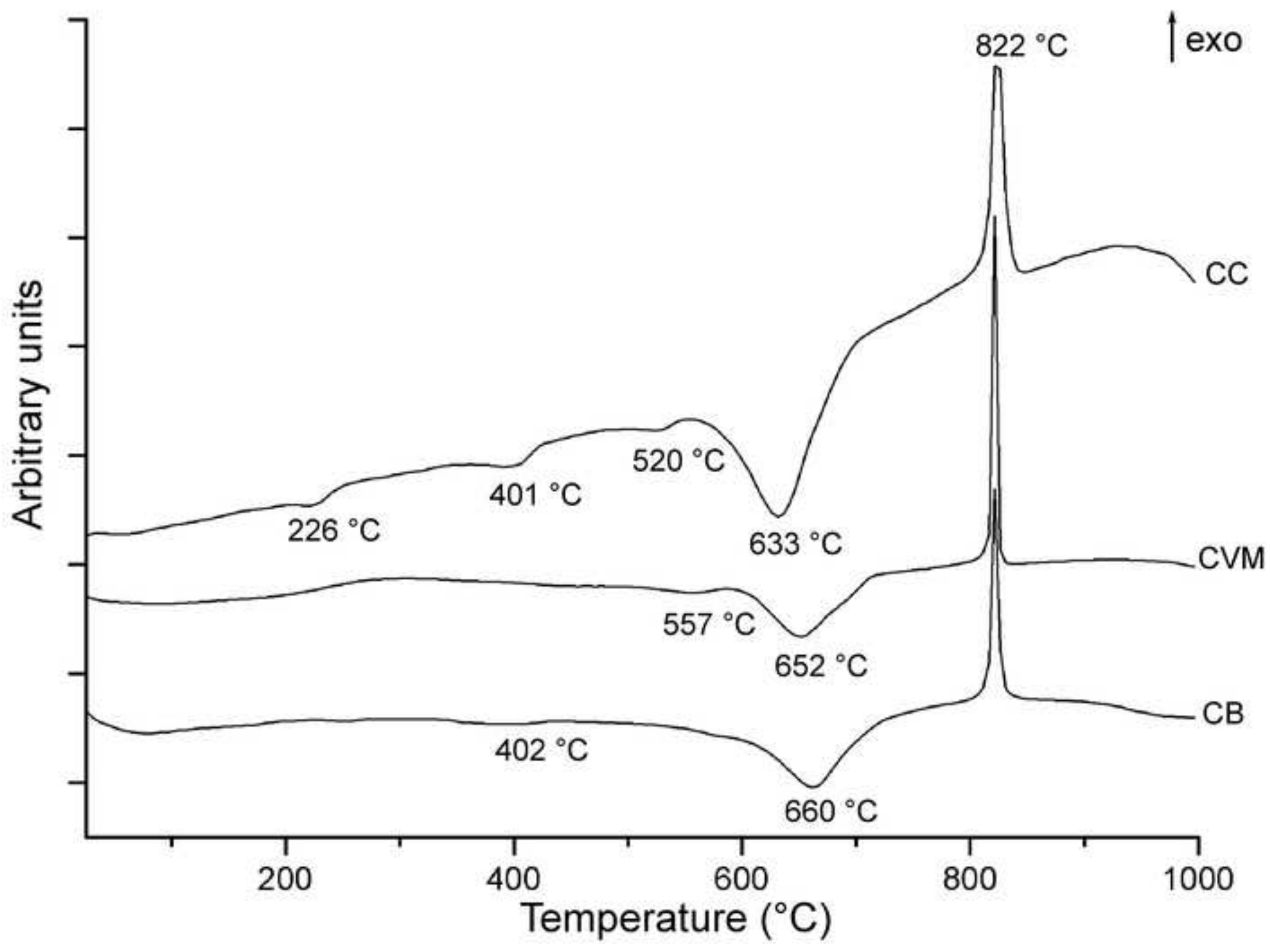


Click here to download Figure: Fig. 6.tif

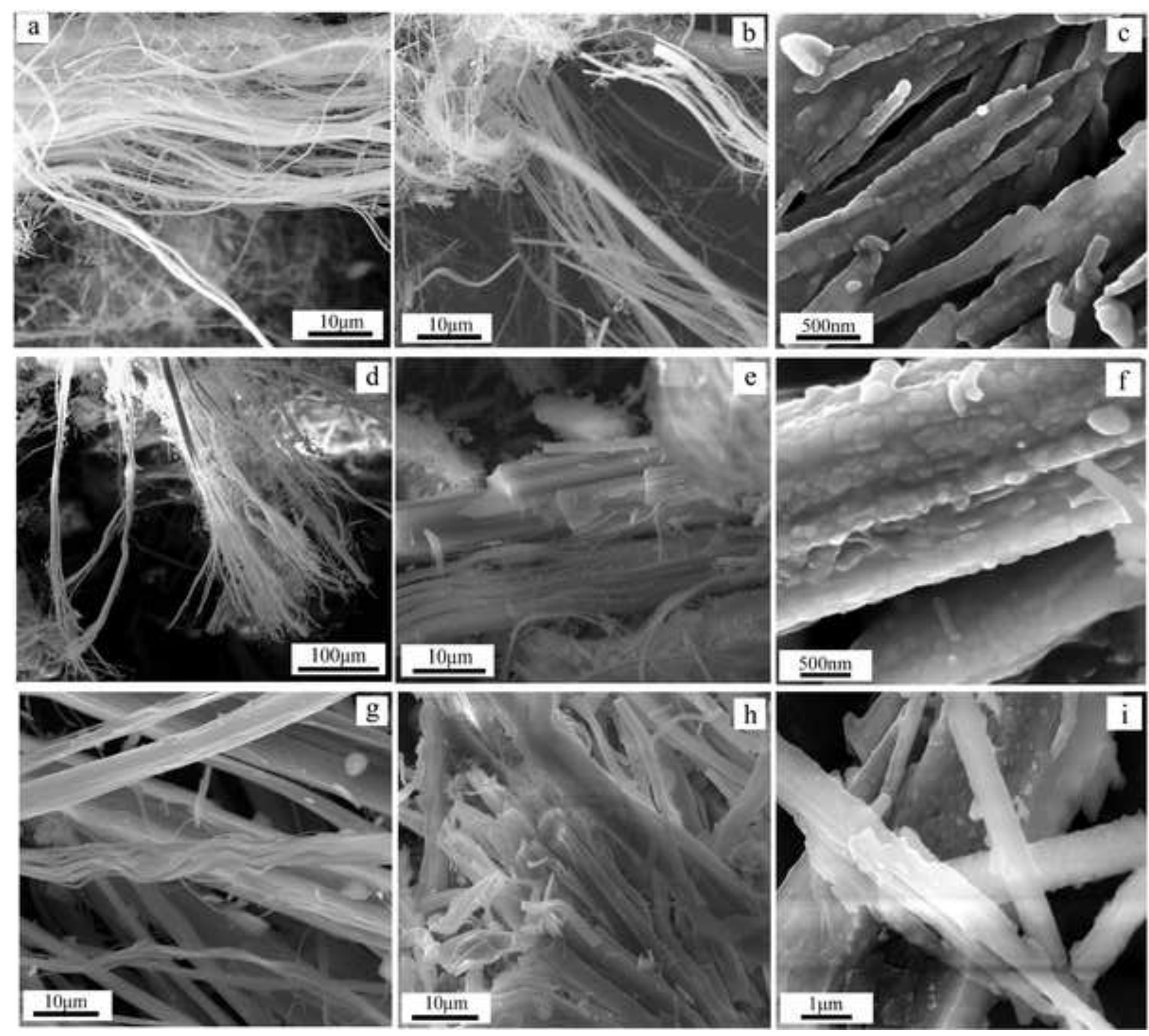




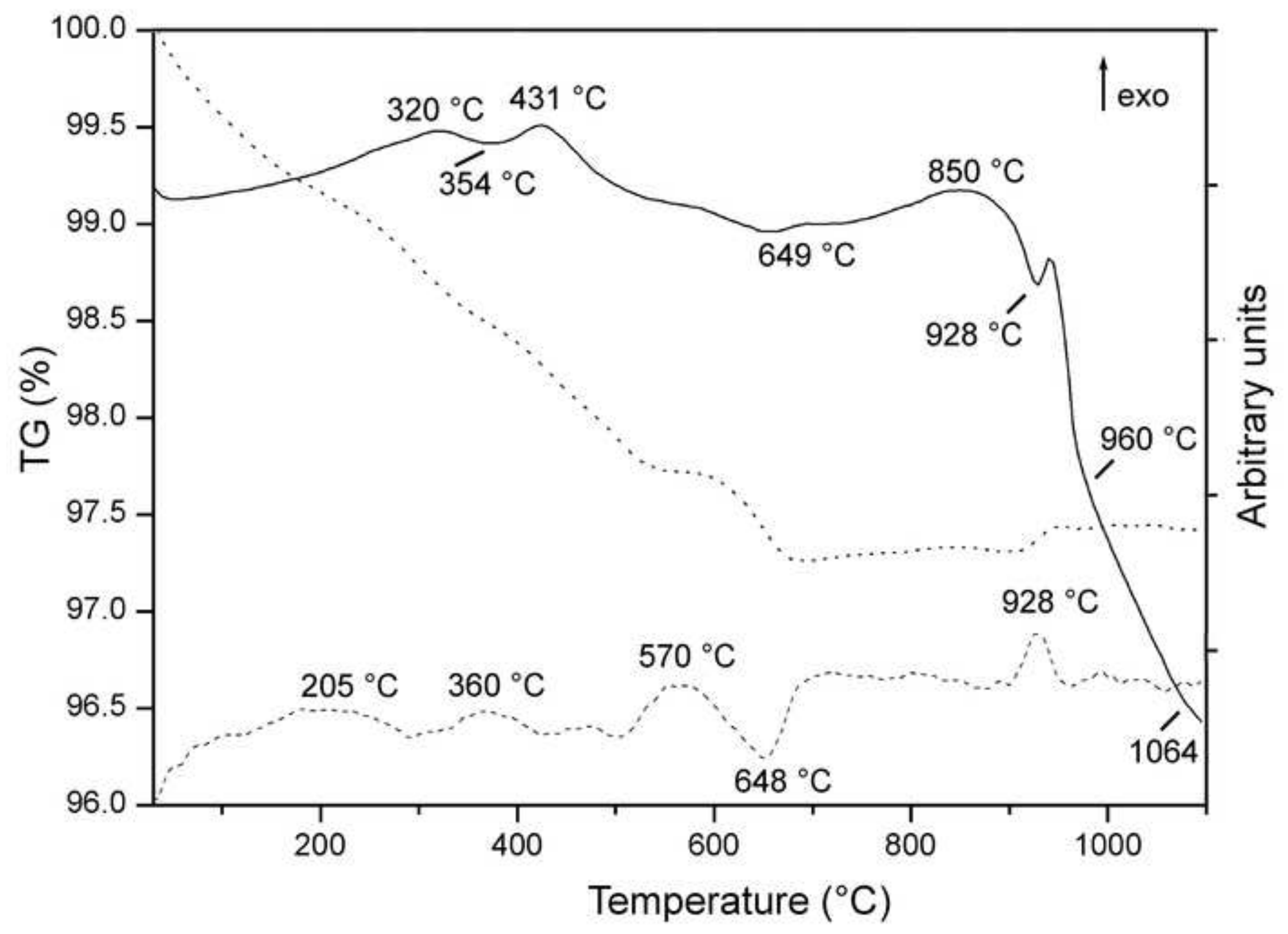




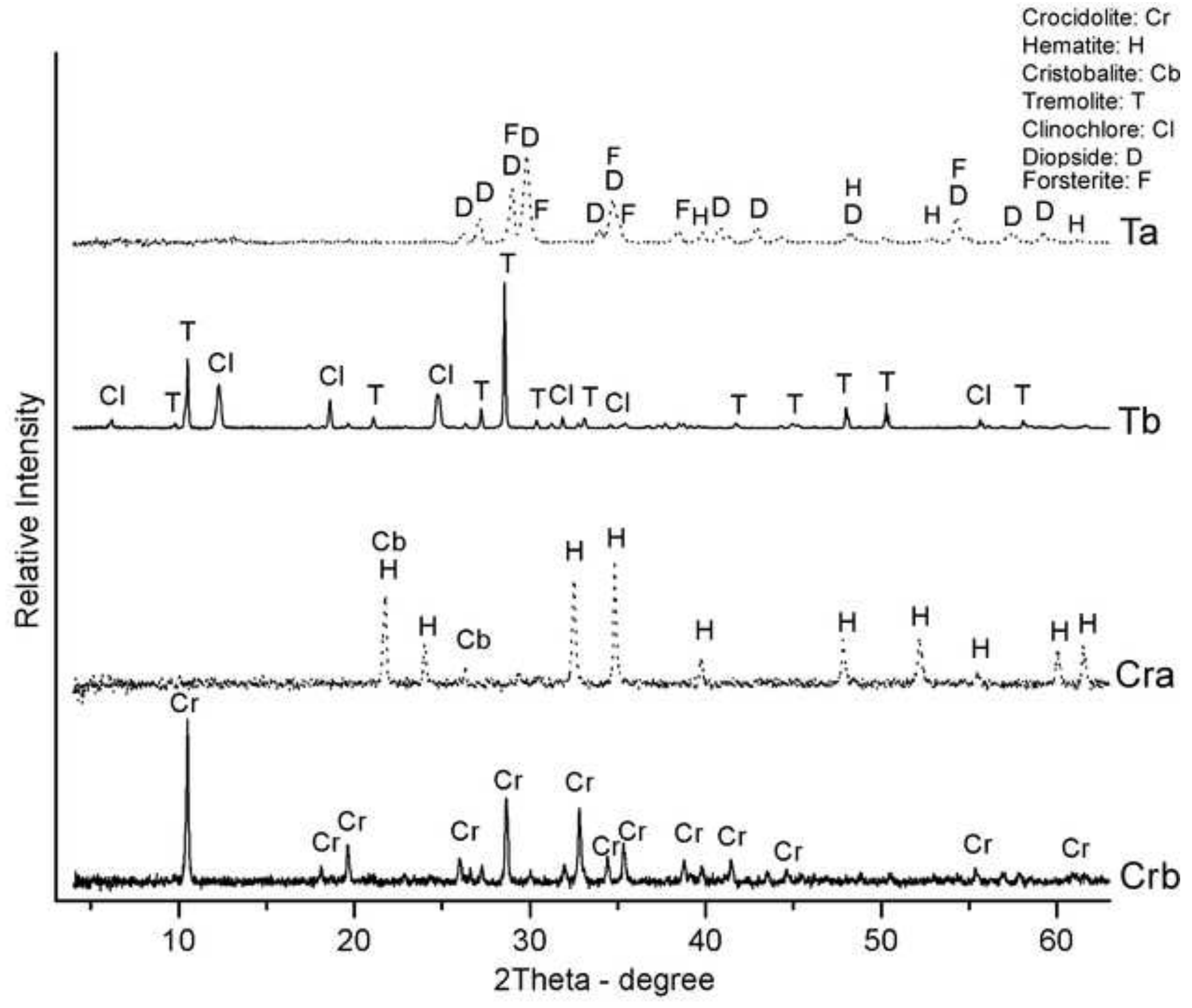

Crocidolite: $\mathrm{Cr}$

Tremolite: $T$

Clinochlore: $\mathrm{Cl}$

Forsterite: $F$

Ta 


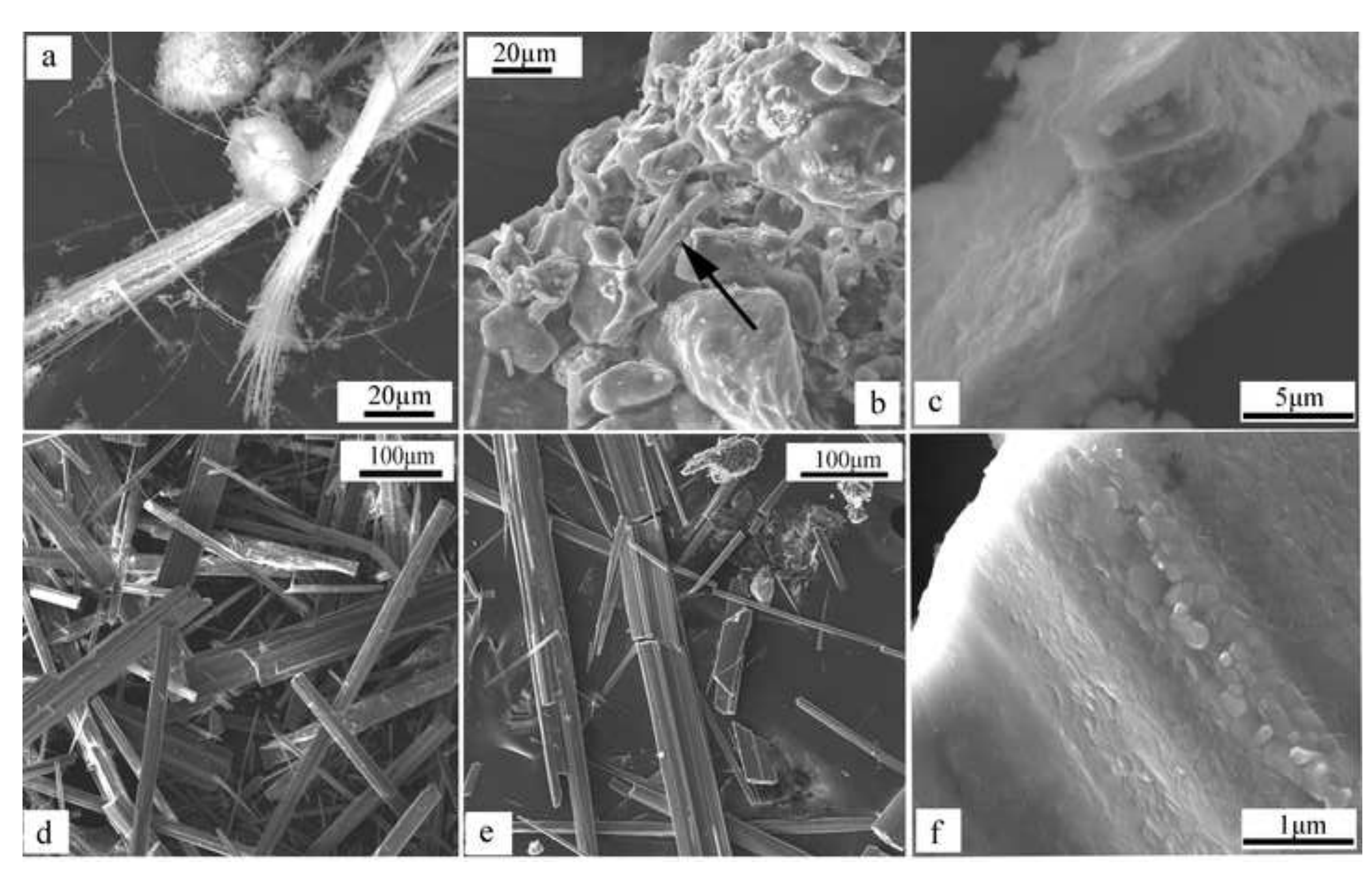

\section{Clck here to download Figure: Fig. 9 .}




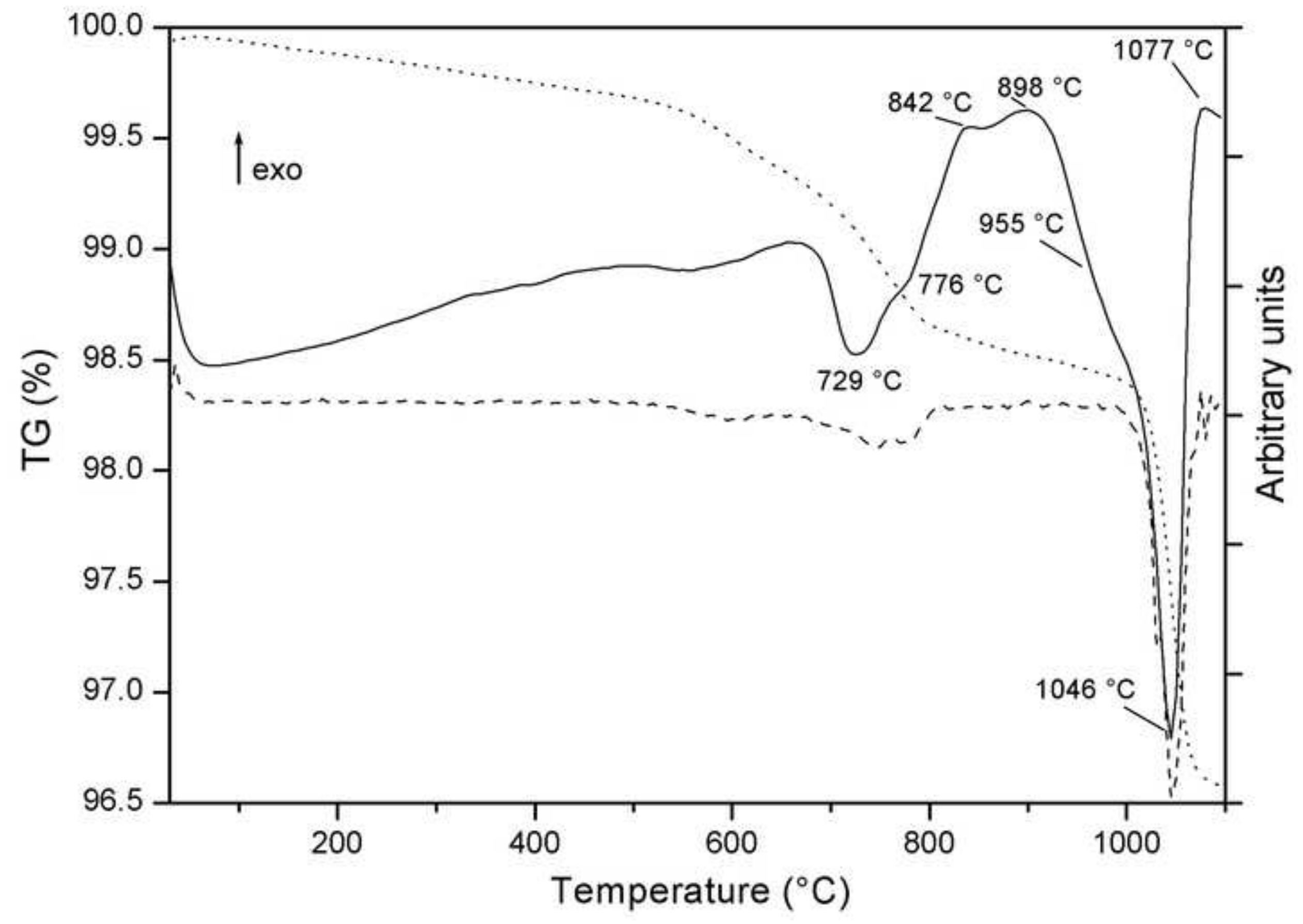




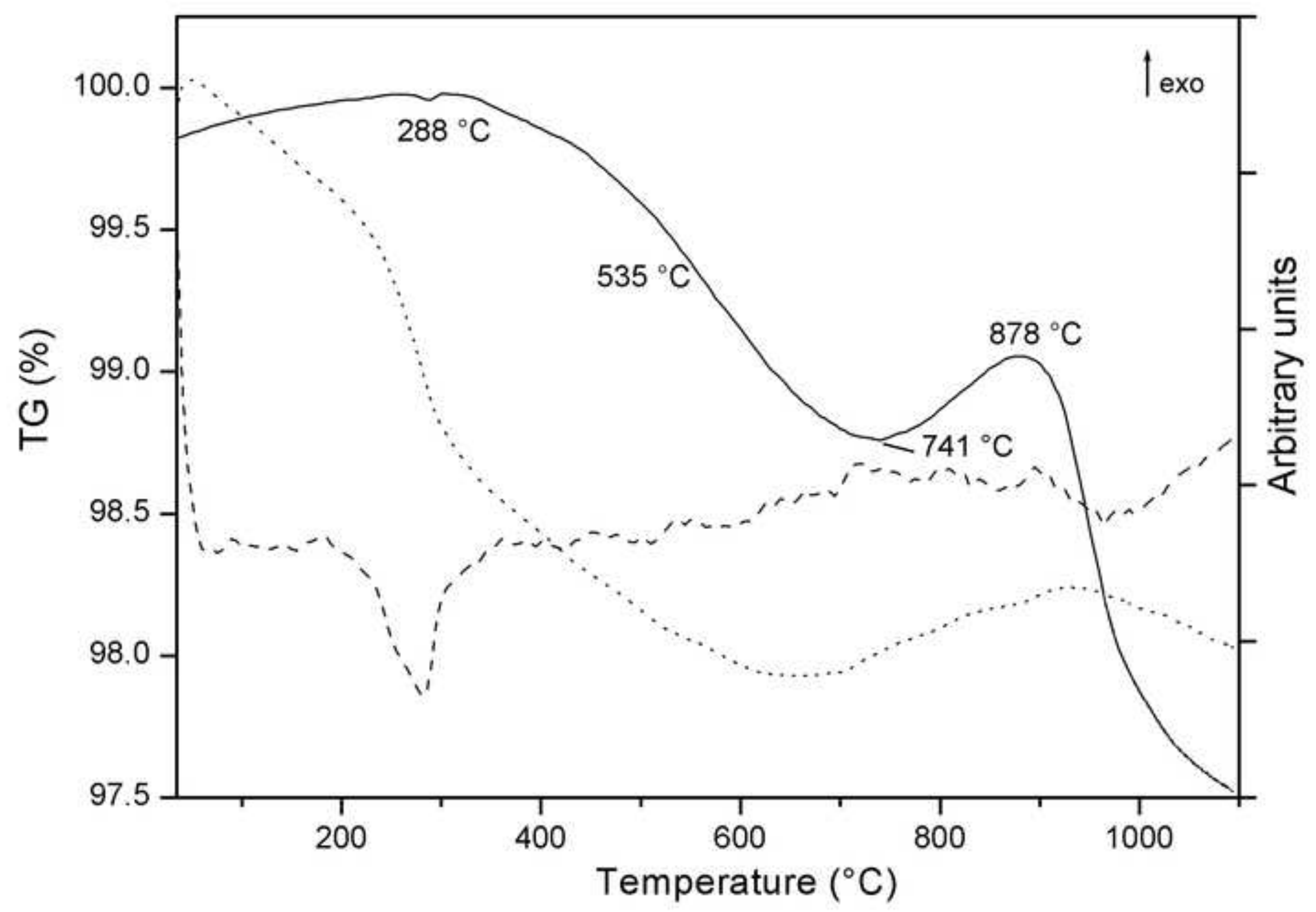




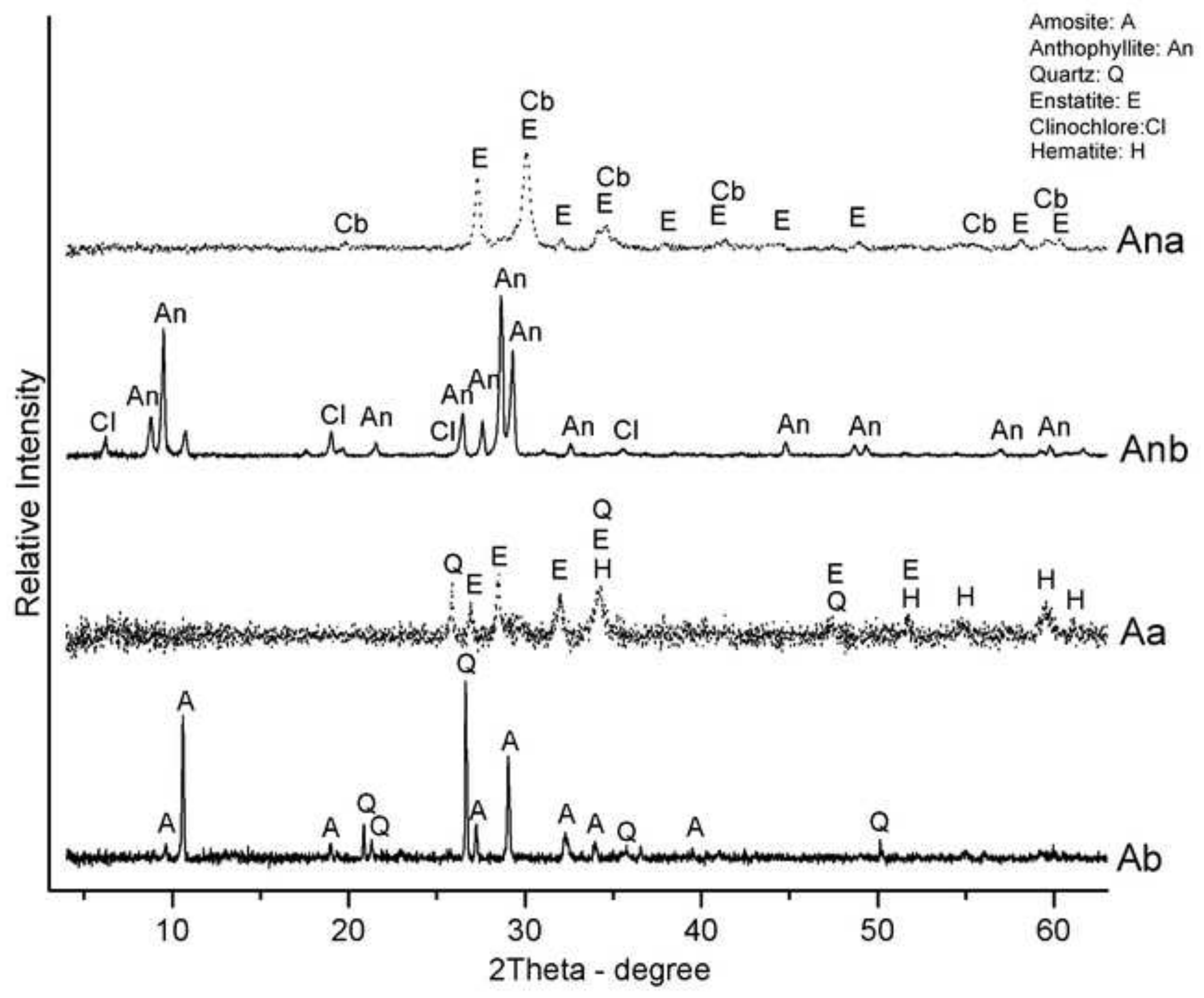



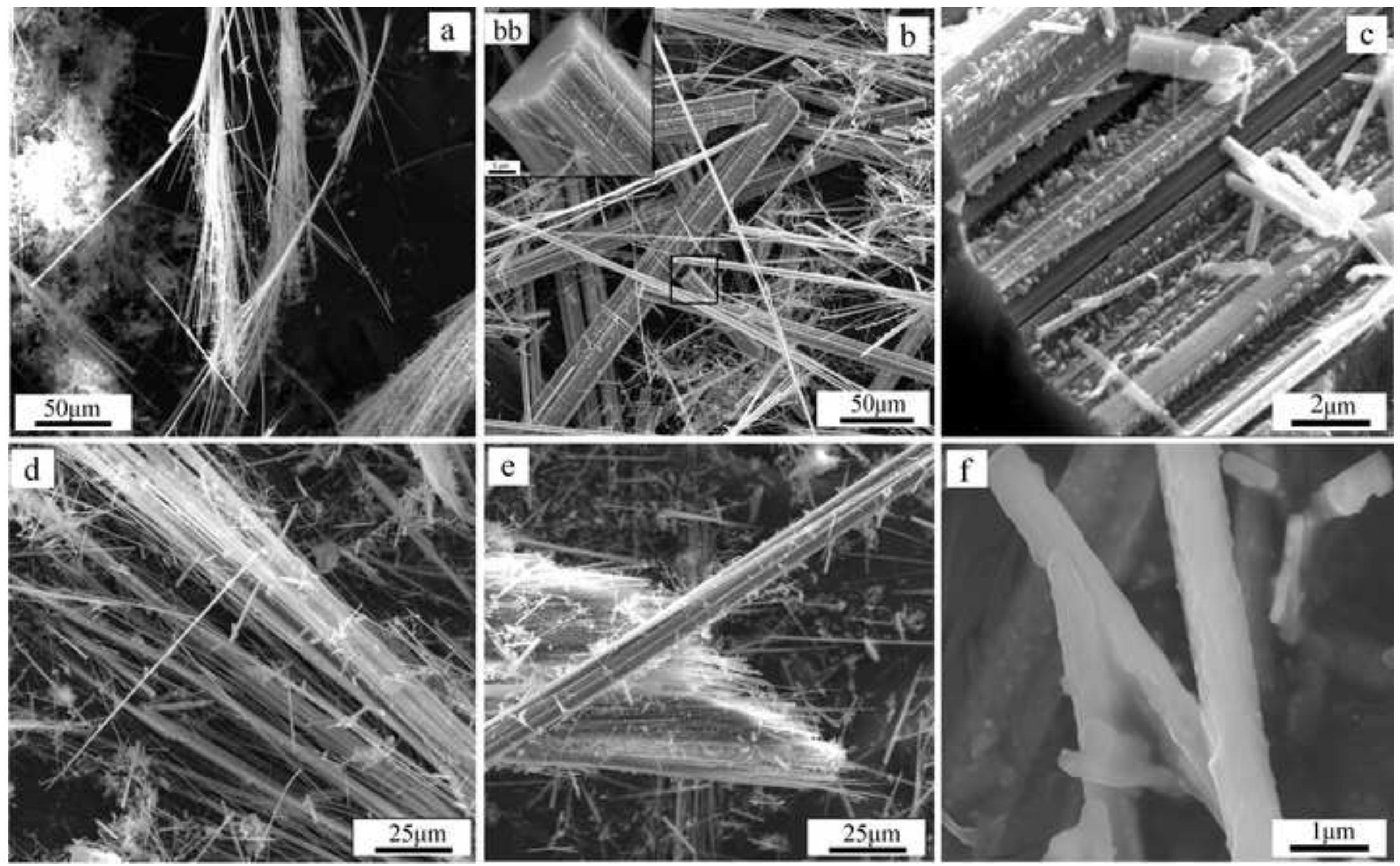


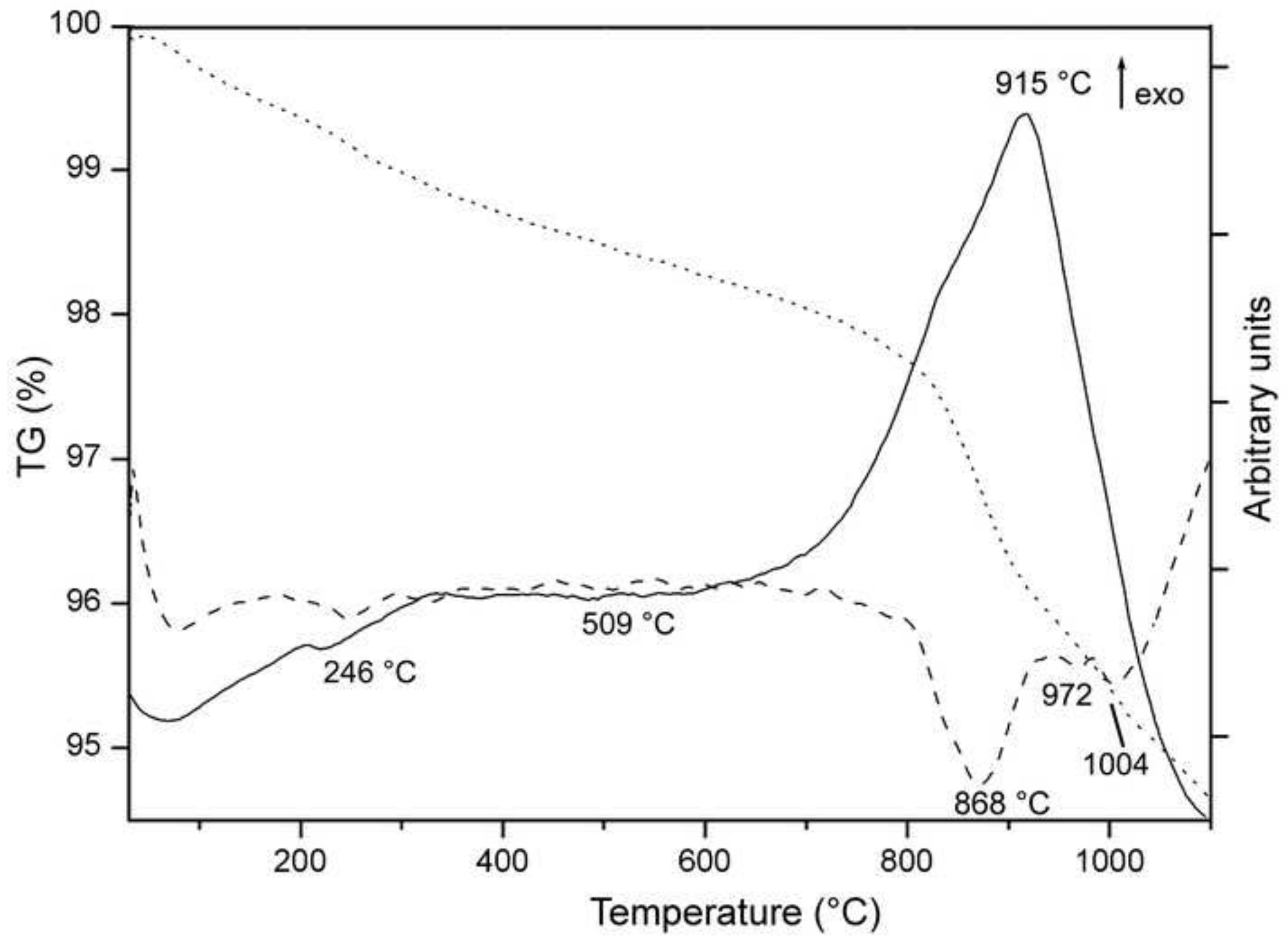




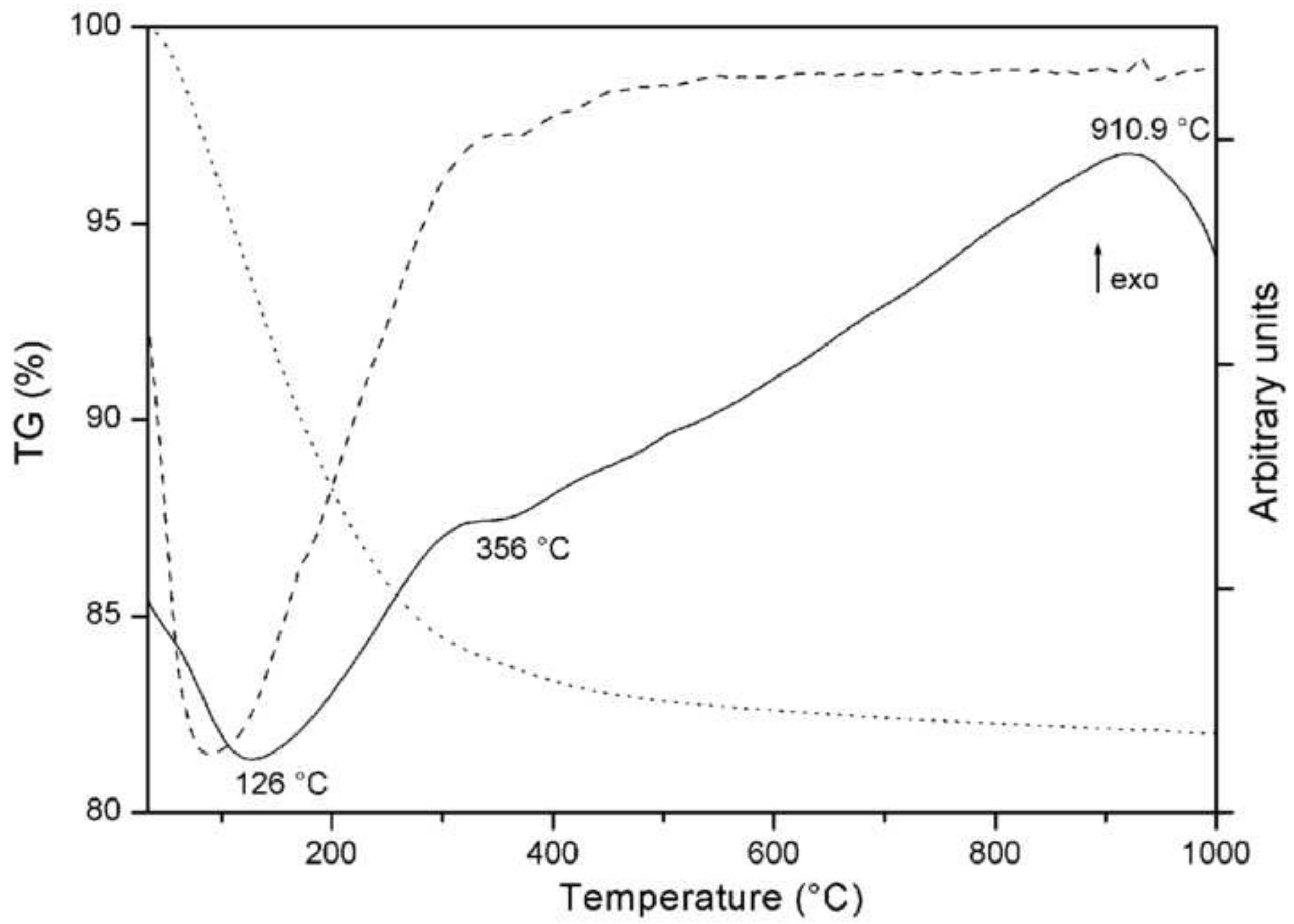




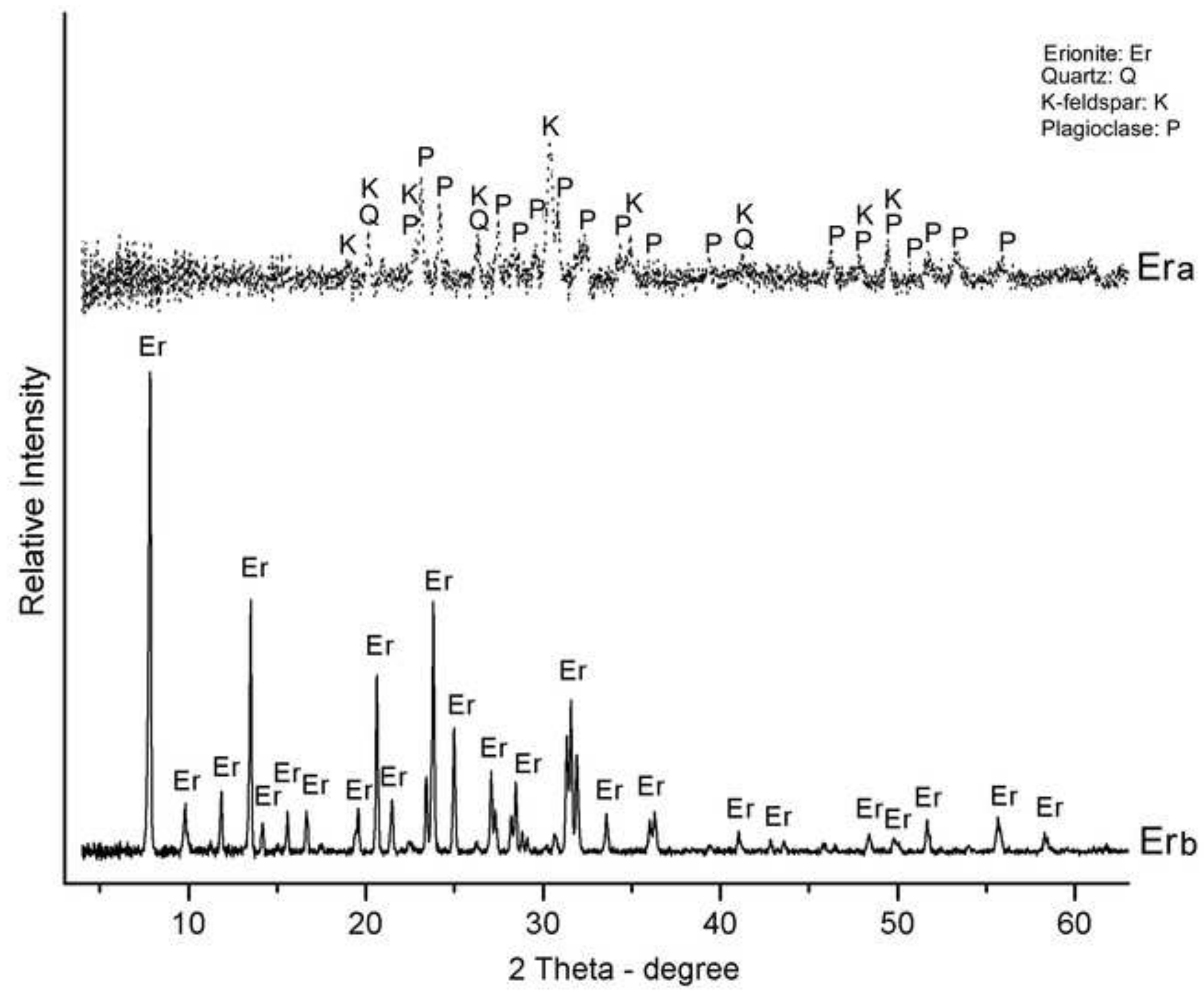


Click here to download Figure: Fig. 17.tif
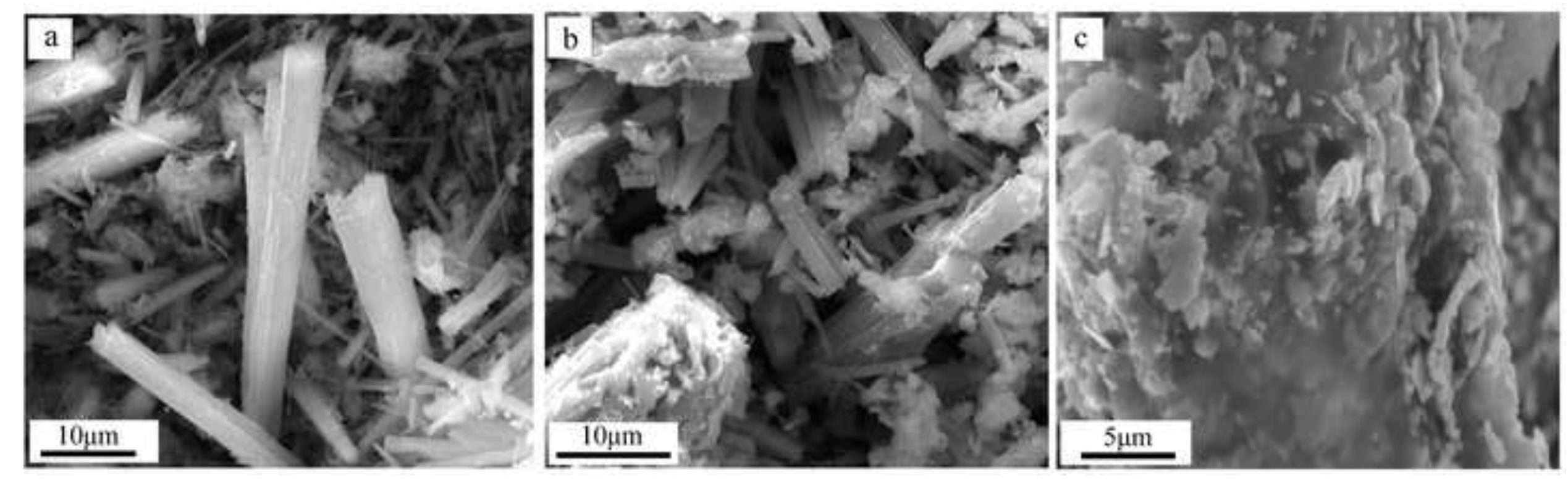

$10 \mu \mathrm{m}$

$5 \mu \mathrm{m}$ 